\title{
Aleksander Malinof Hükümeti ve Türk-Bulgar İlişkilerine Etkisi (Haziran-Eylül 1918)
}

\section{The Government of Alexander Malinov and its Effect on Turkish- Bulgarian Relations (June-September 1918)}

\author{
Fatih Mehmet SANCAKTAR ${ }^{1}$ (1)
}

'Sorumlu yazar/Corresponding author: Fatih Mehmet Sancaktar (Doç. Dr.), Istanbul Üniversitesi, Edebiyat Fakültesi, Tarih Bölümü, Istanbul, Türkiye

E-posta: fatihsancaktar@yahoo.com ORCID: 0000-0002-5501-4982

Başvuru/Submitted: 10.07.2019 Revizyon Talebi/Revision Requested: 03.08.2019

Son Revizyon/Last Revision Received: 29.08.2019

Kabul/Accepted: 10.11.2019

Online Yayın/Published Online: 05.12.2019

Atıf/Citation: Sancaktar, Mehmet Fatih. "Aleksander Malinof Hükümeti ve Türk-Bulgar Iliškilerine Etkisi (Haziran-Eylül 1918)." Türkiyat Mecmuası-Journal of Turkology, 29, 'Milli Mücadele' Özel Sayısı (2019): 127-150. https://doi.org/10.26650/iuturkiyat.655554
ÖZ

Bu çalışma Haziran-Eylül 1918 tarihleri arasındaki Osmanlı-Bulgar ilişkilerini incelemeye çalışmaktadır. Bu meyanda bu zaman aralığında ortaya çıkan sorunların getirdiği sürecin Osmanlı-Bulgar ilişkilerine etkisinin irdelenmesi amaçlanmıştır. I. Dünya Savaşı́nda İttifak Bloğunda yer alan Osmanlı Devleti için Bulgaristan vazgeçilmez bir siyasi coğrafya haline gelmişti. Bu yüzden Osmanlı makamları Bulgaristan'ın sadece dış politikasını değil, iç siyasi gelişmelerini de yakından takip etmişti. Özellikle 1918 başlarında mağlup Rusların Karadeniz filosunun akıbeti ve Kuzey Dobruca'nın geleceği üzerinden Osmanlı Devleti ve Bulgaristan arasında yaşanan tartışmalar, iki müttefik ülke için sarsıntılı bir ortam meydana getirmişti. Bu noktada Bulgaristan'da İttifak Devletleri yanlısı V. Radoslavof yerine muhalif $A$. Malinof'un başbakanlığa getirilmesi her iki ülke ilişkilerinin geleceğinin anlaşılması açısından önemli işaretler vermekteydi. Malinof'un başbakanlığı, sadece iki ülke ilişkileri açısından değil, I. Dünya Savaşı́nın gidişatına ve İttifak Bloğunun kaderine etkisi bu çalışmanın sorguladığı bir problemdir. Bu sorgulama Osmanlı Arşivleri ve hem kendi ülkesinin hem de Bulgarların düşüncelerini ortaya koyan Osmanlı basını incelenerek cevaplanmaya çalışılacaktır.

Anahtar kelimeler: Bulgaristan, Osmanlı Devleti, I. Dünya Savaşı (1918), V. Radoslavof, A. Malinof

\section{ABSTRACT}

This study aims to examine Ottoman-Bulgarian relations from June to September, 1918. The intention of the study is to analyze the effect on Ottoman-Bulgarian relations of the problems which arose from this period. Bulgaria became an indispensable political player for the Ottoman Empire which took part in the Central Power block in World War I. Therefore, the Ottoman Empire paid attention not only to Bulgaria's foreign policy, but also to its domestic affairs. It was particularly the fate of Russia's Black Sea Fleet in 1918 and the trouble between the Ottoman Empire and Bulgaria because of Dobrogea which caused a problematic situation for these allied states. The dissident A. Malinov became prime minister after the premiership of $\mathrm{V}$. Radoslavov, the supporter of Central Powers. This change of power was vital for understanding the future of Ottoman-Bulgarian relations. In addition to 
the relations between the Ottoman Empire and Bulgaria, the premiership of Malinov was also significant for the course of World War I and Central Powers. The issue is also an important question for this study. This question will be dealt with through Ottoman Archives and the Ottoman press which present both Ottoman and Bulgaria's thoughts.

Keywords: Bulgaria, The Ottoman Empire, World War I (1918), V. Radoslavov, A. Malinov

\section{EXTENDED ABSTRACT}

Bulgaria came into prominence for the Ottoman Empire, which entered the First World War on the side of the Central Powers, because its location provided an opportunity for overland connection between the Ottoman Empire and Germany, Austria-Hungary. Therefore, the Ottoman Empire, which had serious issues with Bulgaria, desired the latter to enter the war as an ally of the Central Powers. In fact, the administrators of the Ottoman Empire had started to improve relations with Bulgaria prior to the outbreak of World War I. The defeat of the Allied Powers at the Gallipoli Campaign was determinative for Bulgaria's preference. In addition, Bulgaria tried to guarantee its prospective interest which could be obtained as a result of taking part on the side of the Central Powers. On September 6, 1915, the Convention of Sofia between Bulgaria and the Ottoman Empire rearranged the border, leaving Karaağac and Didymoteicho to Bulgaria. This agreement was the clearest move of Ottoman policy to bring Bulgaria into the war on the side of the Central Powers.

Subsequently, Bulgaria declared war against Serbia and entered the war as an ally of the Central Powers. In this way, the overland connection, which was crucial for the Central Powers, was achieved. Bulgaria had an indispensable strategic location, not only facilitating the campaign of the Central Powers but also achieving overland connection between the Ottoman Empire and Germany, Austria-Hungary. For these reasons, Bulgaria's involvement in the war is significant for the Ottoman Empire. In addition, the Macedonian Front which was established by the Allied Powers was a particular concern for the future and the security of the Central Powers.

That is why the Ottoman Empire followed both Bulgaria's situation on the front and its domestic policy. Although the supporters of the Central Powers were in power, some politicians supported the Allied Powers and Pan-Slavism.

This study aims to reveal the relations between the Ottoman Empire and Bulgaria from the Ottomans' point of view. The study includes the historical period beginning from the premiership of A. Malinov in June, 1918, to the end of the Macedonian Front. It is important to note the effect of the power change on the Ottoman Empire which was brought about in Bulgaria by Malinov.

The change of power in Bulgaria was significant for the Ottoman Empire in several respects. Firstly, Bulgarians might have made an objection to the decisions of the Treaty of Brest-Litovsk and the Treaty of Bucharest which meant several benefits for the Ottoman Empire. Secondly, as mentioned above, Bulgaria's strategic location was significant for 
the Ottoman Empire. Therefore, Malinov's close contact with the Allied Powers may have caused negative consequences for the Ottoman Empire. All in all, the rise to power by an Allied Powers' supporter was crucial. This also gives rise to the question whether Bulgaria might have sat on a dialogue table for peace with the Allied Powers, because the Macedonian Front had not ended yet.

On the whole, both the relations between the Ottoman-Bulgarian and Ottoman- the Central Powers were deeply affected by the armistice of Thessaloniki. In addition, the armistice became a phase of disintegration within the Central Powers. In the light of this, the following crucial questions will be touched upon in this study: Were Ottoman-Bulgarian relations affected negatively because of the power change in Bulgaria? Did Malinov's rise to power have an influence on the course of World War I as well as Ottoman-Bulgarian relations? With the change of power in Bulgaria, how did the Ottoman authorities react to the Bulgarians' approach? These questions will be examined through looking at the correspondence of the Ministry of Foreign Affairs in the Ottoman Archives and the Ottoman press. In addition, the archive of the Ottoman Embassy in Sofia which has recently become available contributed to the study. In this way, the importance of Bulgaria for the Ottoman Empire between June and September, 1918, will be examined through the eyes of Ottoman bureaucracy. Moreover, in the theses and articles which thus far have studied this period, mainly the foreign press and the Ottoman press have been used. However, when the Ottoman newspapers are analyzed, it can be seen that there is an information gap. However, there is also parallelism between the Ottoman archive sources and the newspaper articles. This parallelism was probably derived from the fact that the foreign press was the same and the only source used by both the Ottoman ambassadors and the Ottoman press. 


\section{Giriş}

Osmanlı Devleti 2 Ağustos 1914'de Almanya ile yapılan gizli ittifakın ardından, 29 Ekim 1914'de I. Dünya Savaşı'na katılmıştı. Bu noktada İttifak Bloku saflarında savaşa giren Osmanlı Devleti, dolayısıyla İttifak Güçleri için Bulgaristan coğrafyası önem kazanmıştı. Zira Bulgaristan toprakları, Almanya ve Avusturya-Macaristan Devletleri ile Osmanlı Devleti'nin karadan irtibatını sağlayan bir konuma sahipti. Bu yüzden Osmanlı Hükümeti, 23 Temmuz 1908'de II. Meşrutiyet'in ilanından itibaren önemli sorunlar ve mücadeleler yaşamalarına rağmen Bulgaristan'ın I. Dünya Savaşı’nda İttifak Güçleri yanında savaşa girmesini istemekteydi. ${ }^{1}$ Zaten iktidardaki İttihatçı Osmanlı Hükümeti ve idarecileri, I. Dünya Savaşı'ndan önce bir başka açıdan Balkan Savaşları ardından Bulgaristan ile ilişkilerini iyileştirme, geliştirme yönünde politika takip etmişti. Bu minvalde iki ülke ilişkilerinde bir kriz çıkmaması yolunda önemli çabalar sarf etmişler, Osmanlı-Bulgar sınırında küçük dahi olsa, olumsuz herhangi bir olaya fırsat vermemeye çalışmışlardı. ${ }^{2}$

Ancak Bulgaristan, I. Dünya Savaşı öncesinde İtilaf ve İttifak blokları arasındaki güç dengesinin şekillenmesini beklemiştir. Nitekim Bulgaristan'ın İttifak Bloku içinde I. Dünya Savaşı'na girmesinde, 1915 yılı boyunca süren Çanakkale Cephesi'ndeki sonuç belirleyici olmuştur. ${ }^{3}$ Zira İtilaf Devletleri, bu cephede kazanacağı galibiyetle İttifak Güçlerinin güney kanadındaki Osmanlı Devleti'ni savaş dışı bırakmak istemişti. Bu noktada İtilaf Güçlerinin Çanakkale Cephesi’ndeki başarısızlığı ve mağlubiyeti Bulgaristan'ın tercihini etkilemiştir. Diğer taraftan Bulgar politikacıları, İttifak Bloku içinde savaşa dâhil olmasının getireceği kazanımları garanti altına almaya çalışmıştır. Bu meyanda Bulgar Hükümetinin ilk kazanımı, Almanya'nın de girişimleriyle 6 Eylül 1915'de Sofya'da imzalanan Osmanl1-Bulgar Hudut Tashihi Antlaşması ile Meriç Nehri üzerindeki bazı düzenlemeler ve demiryolu hattının geçtiği Karaağaç ve Dimetoka'nın Bulgaristan'a terki idi. ${ }^{5}$ Bu antlaşma Osmanlı Hükümetinin Bulgaristan'ı kazanmaya dayalı politikasının bir devamı ve en tavizkâr yönü idi.

Bu gelişmelerin ardından İttifak Devletleri yanlısı politikalar takip eden Kral Ferdinand ve Başbakan Liberal Parti lideri Vasil Radoslavof'un 12 Ekim 1915'de Sırbistan'a savaş ilan etmesiyle Bulgaristan İttifak Güçleri safında I. Dünya Savaşı'na dâhil olmuştur. Böylece İttifak

1 Pierre Renouvin, 1. Dünya Savaşı ve Türkiye (1914-1918) (İstanbul: Örgün Yay., 2004), 293-298, 360-364.

2 Fatih M. Sancaktar, "Ali Fethi (Okyar) Bey’in Bulgaristan Sefirliği Dönemindeki Faaliyetleri (Ekim 1013-Aralık 1917)”, Atatürk Araştırma Merkezi Dergisi, 27/81 (2011), 580.

3 Ali Ata Yiğit, "Çanakkale Savaşlarının Ortaya Çıkardığı Stratejik Bir Zorunluluk: Osmanlı-Bulgar Hudud Tashihi Antlaşması”, Bilig, Ahmet Yesevi Üniversitesi Yayınları, 63 (2012), 273-277.

4 I. Dünya Savaşı'nın son evresinde Bulgaristan Başbakanlığına atanan A. Malinof, Eylül 1915'de çizilen yeni Osmanl1-Bulgar sınırının oluşumunda Almanya'nın katkısına sürekli vurgu yapmıştır. "Malinof'un BeyanatıAramızda Hudud Meselesi Yoktur", İkdam, 10 Temmuz 1918, 7694, 1; “Malinof'un Beyanat1-Müttefiklerimizle Beraber hareket Edeceğiz", Vakit, 10 Temmuz 1918, 1.

5 Tevfik Bıyıklığlu, Trakya'da Milli Mücadele I (Ankara: TTK, 1987), 103-107, Angel Dabrov, “1915 Y1lında Bulgar-Türk Sınırının Düzeltilmesi”, XX. Yüzyılın İlk Yarısında Türk-Bulgar Askeri-Siyasi İlişkileri, (Ankara: Genelkurmay Askeri ve Stratejik Etüt Dire Başkanlığg Yay, 2005) 1-7, Ali Ata Yiğit, "Çanakkale Savaşlarının Ortaya Çıkardığı Stratejik Bir Zorunluluk: Osmanlı-Bulgar Hudud Tashihi Antlaşması”, Bilig, 277-280. 
Güçleri ve özellikle Osmanlı Devleti için önemli olan kara bağlantısı/zinciri tamamlanmıştı. I. Dünya Savaşı'nda Bulgaristan, İttifak Devletlerinin ve ordularının mücadelesini rahatlatmasının yanı sıra Osmanlı Devleti için Almanya ve Avusturya-Macaristan ile irtibatı sağlayan vazgeçilmez bir coğrafya halini almıştı. Bu açıdan bakıldığında Osmanlı Devleti için I. Dünya Savaşı sürecinde Bulgaristan'ın ayakta kalması, mücadeleye devam etmesi çok fazla anlam taşımaktaydı. Özellikle İtilaf Devletlerinin Makedonya Cephesi'ni açmasıyla ${ }^{6}$, doğrudan tehlikeye maruz kalan Bulgaristan'ın yapacağı savunma, Osmanlı Devleti ile içinde yer aldığı İttifak Devletlerinin güvenliğini ve geleceğini çok yakından ilgilendiriyordu.

$\mathrm{Bu}$ öneme istinaden Osmanlı Devleti, savaş sürecinde sadece Bulgarların cephelerdeki durumunu değil, aynı zamanda özellikle Bulgar iç politikasını ciddi bir şekilde izlemiştir. Zira Bulgaristan'da hem Bulgar kraliyet ailesinde hem de politikacilarda farklı siyasi eğilimler mevcuttu. Nitekim Bulgaristan'da İttifak Devletleri yanında savaşa girmek isteyenler iktidarda olmasına rağmen, İtilaf Güçleri taraftarı siyasetçiler ve özellikle Rusya yanlısı Rusofiller, Panslavizm emelleri taşıyanlar vardı. ${ }^{7}$ Bu yüzden Osmanlı Hükümeti, Sofya sefirleri Ali Fethi Bey ve daha sonra Safa Bey vasıtasıyla Bulgaristan iç politikasını çok yakından takip etmiştir. ${ }^{8}$

Bu çalışma yukarıda ifade edilen hususlar çerçevesinde Bulgaristan'da Ravdoslavof'un 16 Haziran 1918 'de istifası üzerine ${ }^{9}$ Aleksander Malinof'un hükümeti kurmakla görevlendirilmesi ve Makedonya Cephesi’nin çökmesine doğru ilerleyen süreçte, I. Dünya Savaşı'nda Türk-Bulgar ilişkilerinde yaşanan gelişmeleri Osmanlı makamlarının gözünden orta koymayı amaçlamıştır. Bu noktada Bulgaristan'daki hükümet değişikliğinin Osmanlı Devleti'ni ve yetkililerini ne derece etkilediğinin tespiti önemlidir. Nitekim

6 Birinci Dünya Harbi, Avrupa Cepheleri (Makedonya Cephesi) 7/3, (Ankara: Genelkurmay Harp Tarihi Yayınları, 1967), 9, 22-24.

7 Tarihte Türk-Bulgar Illişkileri (Ankara: Genelkurmay Askeri ve Stratejik Etüt Dire Başkanlı̆̆ı Yayınları, 2004), 87-88, 91, R.J. Crampton, Bulgaristan Tarihi, haz. Nuray Ekici, (İstanbul: Jeopolitika Yay., 2007), 88, Fatih M. Sancaktar, "Ali Fethi (Okyar) Bey'in Bulgaristan Sefirliği Dönemindeki Faaliyetleri (Ekim 1013-Aralık 1917) ", 588. Eylül 1918 tarihli bir Osmanlı askeri istihbaratına göre Bulgar köylüsü, halkı "tamamıyla" Rusofil idi. Bulgar halkının ancak Almanya'da eğitim görmüş "yüzde birlik" bir kesimi Alman taraftarıydı. Bu Rusofiller köylerde gizli örgütler kurarak halkı Rusya ve İngiltere lehine çevirmeye çalışmaktaydı. I. Dünya Savaşı'nda Rusya'ya karşı tavır alışlarını "Biz babamıza isyan ettiğimiz için günahını çekiyoruz" şeklinde değerlendirmekteydiler. Osmanlı Orduyu Hümayun Başkumandanlığı Vekâleti Karargâhı Umumi İstihbarat Şubesi'nden Hariciye Nezaretine, Emniyet-i Umumiye Müdüriyetine, Sofya Ateşemiliterliğine, 5. Ordu Kumandanlığına, 1. Kolordu Kumandanlığına 15 Eylül 1918 tarihli yazı Başkanlık Osmanlı Arşivi (BOA), Hariciye Siyasi (HR. SYS.) 2327/7, lef.1-2.

8 Osmanlı Devleti’nin Sofya Sefiri 13 Ekim 1913-16 Aralık 1917 tarihleri arasında Ali Fethi Bey idi. Ali Fethi Bey'den ardından Sefirlik yapan Safa Bey, görevini I. Dünya Savaşı sonuna kadar sürdürmüştür. 28 Eylül 1913 tarihli Hariciye Nezareti'nin teklifi ve 30 Eylül 1913 tarihli irade-i seniyye ile Ali Fethi Bey'in Sofya Sefirliğine atanmas1, BOA, İrade Hariciye Nezareti İ.HR, 432/42, lef.2; Sadaretten Hariciye Nezaretine 14 Ekim 1913 tarihli yazı, BOA, Bab-1 Ali Evrak Odası (BEO), 4222/316610, lef.1; Sadaretten Hariciye Nezaretine 17 Aralık 1917 tarihli yazı, BOA, BEO, 4222/316610, lef.1. Fethi Okyar, Ü̧̧ Devirde Bir Adam, haz. Cemal Kutay, (İstanbul: Tercüman Yayınları, 1980), 299.

9 Muzaffer Başkaya, “İngiliz Basınına Göre Bulgaristan'ın Birinci Dünya Savaşı’ndan Çekilişi ve Selanik Antlaşması", Akademik İncelemeler Dergisi, 10/1 (2015) 59. 
Osmanlı makamları, Malinof'un iktidara gelişini karşılıklı dostluk ve memnuniyet içeren açıklamalardan ${ }^{10}$ daha öte ilgi ve endişe ile yakından takip etmiştir.

Bulgaristan'daki iktidar değişikliği birkaç açıdan Osmanlı makamları için önem arz etmekteydi. Birincisi Osmanlı Devleti'nin Brest-Litovsk (3 Mart 1918) ve Bükreş Antlaşmalarıyla (7 Mayıs 1918) elde ettiği kazanımların Bulgarların itirazları sonucu alabileceği olumsuz durum idii ${ }^{11}$. Diğeri, yukarıda ifade edildiği üzere Osmanlı Devleti için coğrafi açıdan oldukça önemli olan Bulgaristan'da, daha önceki siyasi tavırlarına istinaden İtilaf Devletlerine yakınlığı ile bilinen Malinof'un takip edeceği politikalardı. Bu noktada henüz iki muhasım blok arasında kesin bir üstünlüğün sağlanamadığı bir dönemde, en azından barış masasına eşit şartlarda oturmak isteyen İttifak Bloku'nun politikalarını etkileyecek ${ }^{12}$ İtilaf Devletlerine yakın bir siyasetçinin iktidara gelmesi, farklı suallerin sorulmasına neden olmaktadır. Bu minvalde henüz Makedonya Cephesi'nin çökmediği ve 29 Eylül 1918 Selanik Antlaşması'nın imzalanmadığı bir safhada, bir başka ifade ile daha erken bir dönemde Bulgaristan'ın İtilaf Bloku ile barış görüşmesine başlama niyetinin, mütareke teşebbüsünün olup olmadığı sorusunu güçlü bir şekilde ortaya çıkarmaktadır.

$\mathrm{Bu}$ değerlendirmeler 1şığında Makedonya Cephesi'nin çökmesinin ardından 29 Eylül 1918'de Selanik Mütarekesi'ni imzalanmasının, sadece Osmanlı-Bulgar değil, aynı zamanda Osmanl-İttifak Devletleri ilişkilerini de etkilediği, İttifak Bloku’ndaki çöküşün bir yönünü oluşturduğu bilinmektedir. Ancak Osmanlı-Bulgar ilişkilerinin Selanik Mütarekesi'nden daha erken bir dönemde bir kriz içine de girmesi, ayrıca sorgulanmalıdır. Bu meyanda Osmanl1-Bulgar ilişkileri, Bulgaristan'daki kabine değişikliğiyle birlikte olumsuz bir şekil almış mıydı? Malinof'un iktidara gelişi Türk-Bulgar ilişkilerinin yanı sıra I. Dünya

10 Talat Paşa'nın A. Malinof'a çektiği 24 Haziran 1918 tarihli telgrafın tercümesi, BOA, HR. SYS. 2330/8, lef.1 ve BOA, Hariciye Nezareti Tercüme Odası (HR.TO.) 548/8, lef.1. Sadrazam Talat Paşa ile Başbakan Malinof arasındaki karşılıklı gönderilen dostluk telgrafları için bk. "Türkiye ve Bulgaristan”, Tanin, 25 Haziran 1918, 3428, 4; "Osmanlı ve Bulgar Başvekilleri Arasında”, Vakit, 25 Haziran 1918, 1.

11 Osmanlı Devleti'nin Bükreş Antlaşmasının üçüncü bölümde yer alan Kuzey Dobruca bölgesi üzerinde elde ettiği kazanımlara dair bk. "Sulh Muahedesinde Dobruca Meselesi”, Tanin, 9 Mayıs 1918, 2; "Bükreş Muahedenamesi Resmi Metin”, Tanin, 13-16 Mayıs 1918; “Dobruca Meselesi Hakkında”, Zaman, 15 Haziran 1918, 4

12 I. Dünya Savaşı'nda hem İttifak hem de İtilaf Bloku'nda 1918 başından itibaren var olan barış eğilimine ve Bloklar içinde farklı politikaların getirdiği çatışmalara dair Avrupa basınında çıkan haberler Osmanlı Hariciyesince yakından takip edilmiştir. Bu meyanda Osmanlı Devleti'nin Kopenhag Sefareti, Haziran 1918'de Avrupa basınındaki barış yönünde eğilimleri artmasını ve Bloklar arasındaki çatışmaları kendi hükümetine iletmiştir. Sefarete göre I. Dünya Savaşına giren ülkelerdeki halkın genelinde harbin getirdiği sıkıntılardan, "yorgunluktan" dolayı barış talebi artmıştı. İngiltere, Fransa ve İtalya arasında fikir ayrılıkları vardı. Benzer şekilde İttifak Bloku'nda da sorunlar baş göstermişti. Bu meyanda Avusturya'da iaşe sıkıntılarından dolayı işçiler "sulh-i münferid" istiyorlardı. Bu blokta Türkiye ve Bulgaristan arasında tavizler sorunu ayrılıkları artırmaktaydı. Kopenhag Sefaretinden Hariciye Nezaretine 24 Haziran 1918 tarihli yazı, BOA, HR. SYS. 2459/9, lef.1. Diğer taraftan 8 Ağustos 1918, İttifak Devletlerinin barış masasına eşit şartlarda oturma düşüncesi için geç kalınacak bir tar h olacaktır. Zira bu tarihte batı cephesinde Alman Ordusu, Fransız ve İngiliz güçleri karşısında tutunamamıştır. Bu mağlubiyet İttifak Bloğu'nda “manevi” çöküş ortaya çıkarmıştır. Âli Türkgeldi, Moudros ve Mudanya Mütarekelerinin Tarihi (Ankara: Türk Devrim Tarihi Enstitüsü Yayınları, 1948), 5. İttifak Devletleri için bir başka husus Osmanlı askeri istihbarat raporuna göre uzun süredir Bulgar kamuoyu, İngilizlerle birleşerek barışa ulaşma arzusu taşımaktaydılar. Osmanlı Orduyu Hümayun Başkumandanlığı Vekâleti Karargâhı Umumi İstihbarat Şubesi'nden Hariciye Nezaretine, Emniyet-i Umumiye Müdüriyetine, Sofya Ateşemiliterliğine, 5. Ordu Kumandanlığına, 1. Kolordu Kumandanlığına 15 Eylül 1918 tarihli yazı BOA, HR. SYS. 2327/7, lef.1-2. 
Savaşı'nın gidişatını etkilemiş miydi? Bulgaristan'daki kabine değişikliğiyle birlikte Osmanlı yetkilileri, Bulgarların girişim veya düşüncelerini ne şekilde takip etmişler ve tepki göstermişlerdi? gibi temel sorular üzerinde durulacak ve ağırlıklı olarak cevapları Osmanlı Arşivi'ndeki Hariciye Nezareti yazışmaları ve Osmanlı basınında aranacaktır. ${ }^{13}$ Böylece Haziran-Eylül 1918 arasındaki bir süreçte Osmanlı Devleti için Bulgaristan'ın ne ifade ettiği, Osmanlı bürokrasisinin gözünden resmedilmeye çalışılacaktır.

Özellikle Osmanlı Devleti'nin Sofya Sefareti arşivinin açılması, bu çalışmaya nicelik ve nitelik açılarından önemli katkılar sağlamıştır. Doğrudan doğruya irdelenmeye çalışılacak tarih aralığındaki bu konu üzerinde tez ${ }^{14}$ ve makaleler bulunmaktadır. Bununla birlikte bu araştırmalarda ağırlıklı olarak Osmanlı basını ve yabancı basın kullanılmıştır. Ancak dönemin Osmanlı basını incelendiğinde bazı bilgi eksiklikleri, geç gelen haberler bulunmaktadır. Bunun dışında basına yansıyan haberler ile Osmanlı belgelerindeki hususlarda paralellik göze çarpmaktadır. Bu durum hem Osmanlı sefirlerinin hem de basınının haber kaynağının yabancı matbuat olmasından kaynaklanmaktadır. Ayrıca Osmanlı Hariciye Nezareti kaynaklarının basını bilgilendirmesi veya haber sızdırması olarak da değerlendirilebilir.

\subsection{Dünya Savaşı'nda Osmanlı Devleti ile Bulgaristan Krallığı Arasında Yaşanan Sorunlar}

I. Dünya Savaşı boyunca müttefik olmalarına rağmen Osmanlı Devleti ile Bulgaristan ilişkileri bazı sorunları üzerinde taşıyarak devam etmiştir. Osmanlı-Bulgar ilişkilerinde ortaya çıkan bu sorunlu alanların başında Müslüman ve Osmanlı vatandaşlarına yapılan ayrımcılık ve Bulgar ordusuna zorla asker alımı gelmekteydi. Bu sorunlar çerçevesinde bakıldığında Osmanlı Devleti ile Bulgaristan arasındaki ilişkilerin Malinof Hükümeti öncesi ve sonrası iyi bir seviyede olduğu veya sağlıklı bir şekilde geliştiği söylenemez. Aslında bu durumun temel nedeni, Balkan Savaşlarının ardından imzalanan 1913 İstanbul Antlaşması’yla Bulgaristan ile ortaya çıkan sorunların bütünüyle halledilememiş olmasıydı. Ancak savaşta aynı blok içinde bulunmak, sorunların ötelenmesine ve kısmen göz ardı edilmesine neden olmuştur. Öncelikle her iki devlet ve halk arasında güven ortamı kurulamamıştı. ${ }^{15}$ Zira I. Dünya Savaşı'na kadar 93 Harbi ve

13 İncelediğimiz dört aylık süreç Osmanlı Meclis-i Mebusan'ın tatil dönemine denk gelmektedir. 31 Mart 1918'de tatile giren Meclis-i Mebusan 1 Ekim 1918'de açılmıştır.

14 Ömer Alkaç, Türk Basınında Mondros Mütarekesi Öncesi Barış Beklentisi (Yüksek Lisans Tezi: Erciyes Üniversitesi, 2015); Zeynep Özbek, 1918 Yllı Türk Basınında Bulgaristan'ın Savaş Politikasıyla İlgili Değerlendirmeler (Yüksek Lisans Tezi, Erciyes Üniversitesi, 2014)

15 Sofya Ateşemiliterliğinin bir istihbarat raporu, Osmanlı-Bulgar ilişkilerindeki olumsuz havaya doğrudan doğruya işaret etmektedir. Bu istihbarat raporuna göre, Bulgar kamuoyu, "hiçbir zaman samimiyet içinde olmamıştı" ve Almanlarla birlikte hareket etmenin gerekli olduğunu düşündüklerinden dolayı Osmanlı Devleti ile ittifakı zaruri görmüşlerdi. Bulgar halkı ve ordusu içinde Osmanlı-Bulgaristan sınırının Çatalca'ya kadar uzaması yönünde bir "heyecan” da vardı. Bu istek Bulgarların "milli” politikası idi. Osmanlı Orduyu Hümayun Başkumandanlığı Vekâleti Karargâhı Umumi İstihbarat Şubesi’nden Hariciye Nezaretine, Emniyet-i Umumiye Müdüriyetine, Sofya Ateşemiliterliğine, 5. Ordu Kumandanlığına, 1. Kolordu Kumandanlığına 15 Eylül 1918 tarihli yazı BOA, HR. SYS. 2327/7, lef.1-2. 
özelikle 1908'den itibaren Osmanlı toprakları üzerinde sürekli büyüyen bir Bulgaristan Krallığ mevcut idi. Bu durum Osmanlı Devleti için sadece toprak kayıpları anlamına gelmemekteydi, aynı zamanda birçok diplomatik, sosyal sorunları da ortaya çıkarmıştı. Bir yandan vatandaşlık ve göç, diğer taraftan Bulgaristan'da yaşayan Türk topluluğun hakları ve hayatı bu sorunların temelini oluşturmaktaydı. Ayrıca İstanbul Anlaşması'na rağmen sınır ve nüfus mübadelesi sorunları çözümlenememişti. ${ }^{16}$ I. Dünya Savaşı esnasında Sırbistan'ın kontrolündeki Makedonya'yı Bulgaristan'ın işgal ederek kendi topraklarına katması, sorunların çerçevesini genişletmiştir. Bulgar Hükümetleri kontrolü altındaki topraklarda, Türkleri ve Müslümanları zorla silah altına almış ve Bulgar ordusunun farklı birimlerinde kullanmıştır. ${ }^{17}$ Yine Bulgar yetkilileri Makedonya' da Müslümanlara “mezalim” uygulamıştı. ${ }^{18}$

Bulgaristan'da I. Dünya Savaşı'nda Müslümanlara ve Osmanlı vatandaşlarına karşı yukarıda ifade edildiği üzere ayrımcılık da yapılmıştır. Bu noktada savaş esnasında Bulgaristan'da gıda ve yiyecek sorunu ciddi boyutlara ulaşması üzerine, Bulgar hükümeti ekmek dağıtımını kişi başına 200 grama kadar indirmişti. Ekmeğin gramının azaltılması, fiyat artışı ve "açlık" endişesini ortaya çıkarmış, fakirlerin ve işçilerin protestosuna, hatta bazı bölgelerde "yağmaya" neden olmuştu. Bu protestolar sonucu "yaralanma" ve "ölümler" yaşanmıştı. Ancak ekmeğin gramının azaltılması kararı, Bulgar vatandaşı olmayanları daha fazla etkilemiştir. Zira Bulgaristan'da Müslümanların ve hâlâ Osmanlı Devleti vatandaşı statüsü taşıyanların sayısı oldukça fazla idi. Nitekim Filibe'de Osmanlı vatandaşlarına verilen ekmek “kuponları”" geri alınmış ve Bulgarlara dağıtılmıştı. ${ }^{19}$

\subsection{Aleksander Malinof Hükümetinin Kurulması ve Osmanlı-Bulgar İlişkileri}

Aleksander Malinof'un iktidara gelmesinden önce Osmanl-Bulgar ilişkilerinde, yukarıda ifade edildiği üzere Türklere yapılan zulümler, toprak tavizleri gibi hususlar ön plana çıkmıştı. Malinof'un iktidarı ile birlikte bu sorunlar devam etmiş, hatta yeni veçheler kazanmış olduğu gibi, Osmanlı Devleti'nin I. Dünya Savaşı'ndaki geleceğini ciddi anlamda etkileyecek sulh-i münferid hususu da ortaya çıkmıştı. Böylece Osmanlı-Bulgar ilişkilerinde güvensizlikler ve endişeler daha belirgin hale gelmiştir. Bu güvensizliklerde Malinof'un kendisi ve partisinin daha önce takip ettiği siyaset önemli bir etkendi. Bu noktada Malinof ve siyasi düşüncelerinden bahsedilmelidir.

16 Sadaretten Hariciye Nezaretine 6 Haziran 1918 tarihli yazı, BOA, BEO, 4519/338853; Hariciye Nezaretinden Dahiliye Nezaretine 10 Ağustos 1918 tarihli yazı, BOA, Dahiliye Nezareti İdare-i Umumiye Ek Belgeleri, (DH.İ.UM.EK.), 111/122.

17 Sofya Sefaretinden Hariciye Nezaretine 25 Şubat 1916 tarihli yazı, BOA, HR. SYS, 2418/23, lef.1-2.

18 Dahiliye Nezaretinden Hariciye Nezaretine 24 Ağustos 1918 tarihli yazı, BOA, HR. SYS. 2458/6, lef.2; Sofya Sefaretinden Hariciye Nezaretine 4 Temmuz 1918, BOA, HR. SYS. 2455/51, lef.1. Makedonya ve Gümülcine'deki Türk ve Müslümanlara yapılan baskılara dair Hariciye Nezaretinden Sofya Sefaretine 23 Mayıs 1918 tarihli yazı, BOA, Hariciye Nezareti Şifre Kalemi (HR. ŞFR.)04, 421/8, lef.3-5 ve Dedeağaç Şehbenderliğinden Sofya Sefaretine 1 Haziran 1918 tarihli yazı, BOA, HR. ŞFR.(04), 421/8, lef.6/1-3.

19 Filibe Şehbenderliğinden Sofya Sefaretine 20 ve 27 Mayıs 1918 tarihli telgraflar, BOA, HR.ŞFR. (04) 921/126, lef.3, 5 . 


\section{Demokrat Parti Lideri Aleksander Malinof ve Hükümetinin Kurulması}

Bulgaristan'da I. Dünya Savaşı öncesi Tsonkovistler (İlerici Liberal Firka) lideri Stoyan Danev'in 17 Temmuz 1913'de başbakanlıktan istifa etmesinin ardından Vasil Radoslavof, üç partinin iştirak ettiği bir çoğunluk hükümeti kurmuştur. Radoslavof'un başbakanlığındaki bu hükümeti, farklı liberal gruplar desteklemişti. Bu hükümet İttifak Devletleri yanında yer almıştı. ${ }^{20}$ Ancak Bulgaristan'ın savaşa girmesinden itibaren Radoslavof Hükümeti, sürekli muhalif partilerin eleştirilerine maruz kalmıştır. Özellikle 1917'nin son aylarından sonra savaş aleyhtarı gösteriler yapan çiftçi, radikal sosyalist ve İtilaf yanlısı partilerin ve grupların muhalefeti artmışt1. ${ }^{21}$

16 Haziran 1918'de çeşitli siyasi oluşum ve parti destekli Radoslavof Hükümeti, iç politik çekişmeler ve asker ile yaşadıkları uyumsuzluk sonucu istifa etmiştir. Bu hükümeti destekleyen Ístanbulist Partisine mensup bakanlar istifa etmiş, Bulgar ordusu Başkomutanı General Jekof, Radoslavof'a karşı “şedid” bir muhalif tavır benimsemişti. ${ }^{22}$ Bulgaristan siyasi sahnesinde artık Radoslavof hükümetinin temsil kabiliyetinin kaybolduğu düşüncesi hâkim olmuştu. Bu yüzden Bulgaristan'da toplumun bütün kesimlerini temsil eden ve farklı siyasi parti ve oluşumları bünyesinde barındıracak karma bir hükümetin kurulması ihtiyacı doğmuştu. ${ }^{23}$

$\mathrm{Bu}$ gelişmeler üzerine Bulgar Kralı Ferdinand ${ }^{24}$, Demokrat Parti lideri Aleksander Malinof'a hükümeti kurma görevini 16 Haziran 1918'de vermiştir. Ancak beklenenin aksine yeni hükümetin kurulmasına Bulgaristan'daki bütün kesimler katılmamıştır. ${ }^{25} \mathrm{Bu}$ çerçevede Radoslavof, Tonçef, Sosyalistler, Çiftçi Grubunun yeni hükümete destek vermesi beklenmemekteydi. Bu siyasi grup ve yapıların dışındaki partilerin desteğiyle Malinof Hükümetinin kurulma ihtimali vardı. Aslında bu destek yeni hükümette bakanlık düzeyinde

20 Ayrıca Radoslavof Hükümeti kredi karşılı̆ı̆ında Bulgaristan'da bazı demiryolu hatlarının yapımı ve madenlerin işletme hakkını Almanlara vermiști. Crampton, Bulgaristan Tarihi, 121-123.

21 Crampton, Bulgaristan Tarihi, 127-128

22 Liberallerin liderliğinde İstanbulist ve Toncevist firkaların desteğiyle Radoslavof Hükümeti kurulmuştu. Hükümetin düşmesine Radoslavof'u destekleyen İstanbulist firka üyelerinin kabineden istifa etmesi, iaşe sorununu çözümlenememesi, uzun süren savaşın kabineyi aşındırması, sosyalistlerin iaşe ve savaşa dair eleştirileri ve bütün bu olumsuzluklara istinaden daha kapsayıcı ve mütecanis bir hükümete ihtiyaç duyulması gibi nedenler etkili olmuştu. "Bulgaristan'da Kabine Buhranı", Tanin, 18 Haziran 1918, 1; "Bulgaristan'da Kabine Buhranı", Tanin, 19 Haziran 1918, 1; "Radoslavof'un Esbab-1 İstifası", Tanin, 20 Haziran 1918, 1, "Radoslavof'un İstifası Etrafinda", Tanin, 21 Haziran 1918, 4; "Yeni Bulgar Başvekili", Vakit, 19 Haziran 1918, 1; "Bulgar Buhran-1 Vükelası", Tasvir-i Efkâr, 20 Haziran 1918, 1

23 Sofya Sefaretinden Hariciye Nezaretine 19 Haziran 1918 tarihle yazı, BOA, HR. SYS. 2330/3, lef.1; Viyana Sefaretinden Hariciye Nezaretine 20 Haziran 1918 tarihli telgraf, BOA, HR. SYS. 2330/4, lef.1; Hariciye Nezaretinden Berlin Sefaretine 27 Haziran 1918 tarihli şifre telgraf, BOA, HR. SYS. 2330/4, lef.2. Külnirche Beitung/Kölnijche Çanyung Gazetesi, 18 Haziran 1918 tarihli sayısında İstanbulistlerin Demokrat parti lideri Malinof'u desteklemeleri halinde Radoslavof Hükümeti'nin düşme ihtimalinden bahsetmiştir. Hariciye Nezaretinden Sadarete 25 Haziran 1918 tarihli yazı, BOA HR. SYS. 2454/74, lef.1.

24 Kral Ferdinand, Osmanlı Padişahına çektiği telgrafında Doktor Radoslavof'un istifasını, "bazı" iç siyasi sebeplerden kaynaklandığını ileri sürmüştür. Bulgar Kralı Ferdinand'ın Sultan Reşat'a çektiği 23 Haziran 1918 tarihli telgrafin tercümesi, BOA, HR. SYS. 2330/7, lef.1.

25 Malinof geniş tabanlı bir hükümet kurmak için Bulgar parlamentosundaki Radikal Sosyalist guruplar dışında bütün muhalif firka liderleriyle 18 Haziran 1918'de bir görüşme yapmıștır. "Yeni Bulgar Kabinesi”, Tanin, 20 Haziran 1918, 1; "Malinof'un Müzakeratı", Tasvir-i Efkar, 20 Haziran 1918, 1; "Bulgaristan'da Yeni Kabineyi Kim Teşkil edecek?”, Sabah, 19 Haziran 1918, 1; “Malinof Kabinesi”, Sabah, 20 Haziran 1918, 1. 
temsilden daha çok Malinof Hükümetinin kurulmasına yardım etmek, dişarıdan destek vermek şeklinde idi. Bu yüzden görevlendirilen Malinof'un başlangıçta yeni hükümeti kurup kuramayacağı dahi kesin değildi. ${ }^{26}$ Nitekim Bulgaristan'da hükümetin kurulması aşamasında Malinof, Osmanlı Devleti'nin Sofya Sefiri Safa Bey'i ziyareti esnasında ${ }^{27}$ Radoslavof'un dahi kendisine destek vereceğine dair kanaatini dile getirmişti. Hatta kısa bir süre sonra açılacak Sobronya'da yeteri kadar destek alamaması halinde hükümetten çekilecekti. ${ }^{28}$

Sonuçta Malinof, sadece "radikallerin" iştirak ettiği ve Radoslavof Hükümetine muhalif olan diğer siyasi yapı ve partilerin dışarıdan destek verdiği bir kabineyi 21 Haziran 1918'de kurabilmiştir. Bu noktada Bulgaristan'daki iç siyasi süreci değerlendiren Sofya Sefiri Safa Bey'e göre Bulgar muhalefeti sadece Radoslavof hükümetini düşürmek için bir araya gelmişti. Nitekim destek çıkan partiler kabinede yer almak yerine, yardımcı olacaklarına dair sadece "şifahen" söz vermişlerdi. Hatta destek çıkan bu siyasi partiler, kendi gazetelerinde Malinof Hükümetinin kurulmasının hemen ardından eleştirmekten de geri durmamışlardı. Bu yüzden siyasi partilerin Bulgar Parlamentosu Sobronya'da sözlerini tutmaları dahi “şüpheli” idi. ${ }^{29}$

Ancak Bulgaristan'ın içinde bulunduğu İttifak Blokunda, Malinof Hükümetine hangi siyasi grubun destek vereceği ve kimlerden oluşacağından daha önemli bir endişe vardı. $\mathrm{Bu}$ endişe Bulgaristan siyasetinde güçlü olan Rusofil ve İtilaf Bloğu taraftarı parti ve siyasetçilerin Malinof Kabinesine girmesi idi. Zira Malinof Kabinesine girecek bakanların siyasi düşünce ve tavırları, İttifak Blokundaki Bulgaristan'ın savaş ve dış politikada takip edeceği yol hakkında fikir verecekti. Daha açık bir ifadeyle ifadeyle Malinof Hükümeti İttifak Bloğu'nda bir zayıflık meydana getirebilir miydi? ${ }^{30}$

26 Sofya Sefaretinden Hariciye Nezaretine 18 Haziran 1918 tarihli yazı, BOA, HR. SYS. 2330/3, lef.1. Malinof hükümetine Demokrat ve Radikal partilere mensup milletvekillerinin desteklenmesi beklenmekteydi. Hariciye Nezaretinden Berlin ve Viyana Sefaretlerine 27 Haziran 1918 tarihli yazı, BOA, HR. SYS. 2330/6, lef.2; "Bulgaristan'da Yeni Kabine ve Matbuat", Tanin, 17 Temmuz 1918, 2.

27 Malinof 19 Haziran 1918'de Osmanlı Devleti'nin Sofya Sefaretini ziyaret etmiştir. "Malinof Osmanlı Sefarethanesinde", Tanin, 24 Haziran 1918, 2.

28 Sofya Sefaretinden Hariciye Nezaretine 22 Haziran 1918 tarihli telgraf, BOA, HR. SYS. 2330/6, lef.3.

29 Sofya Sefaretinden Hariciye Nezaretine 4 Temmuz 1918 tarihli yazı, BOA, HR. SYS. 2455/51, lef.1. Malinof, Stamboliyski liderliğindeki Çiftçi Partisini kendi kabinesine dâhil etmek istemiştir. Ancak bu istek kabul görmemiştir. Crampton, Bulgaristan Tarihi, 128. Yeni kabinede Malinof Başbakanlık ve Hariciye Nazırlığını uhdesine almıştı. Kabine ağırlıklı olarak Malinof'un partisi Demokrat Fırka üyelerinden oluşmaktaydı. Ayrıca bu kabinede Radikal Fırkalardan 2 kişi bulunmaktayd1. "Bulgaristan Kabinesi” Vakit, 22 Haziran 1918, 2, "Bulgar Kabinesi Teşekkül Etti”, Tanin, 23 Haziran 1918, 4; "Bulgaristan'da Yeni Kabine”, İkdam, 24 Haziran 1918, 1. Osmanlı basınında yeni Bulgar Kabine üyeleri tek tek tanıtılmıştır. "Yeni Kabine Erkânı", Tanin, 24 Haziran 1918, 2, "Bulgar Kabinesi Teşekkül Etti”, İkdam, 23 Haziran 1918, 1; "Bulgar Nazırlarının Şahsiyetlerine Dair”, İkdam, 30 Haziran 1918, 2.

30 Cenevre Başşehbenderliğinden Hariciye Nezaretine 26 Temmuz 1918 tarihli yazı ekinde La Tribune de Geneve gazetesinde Turcs et Bulgaria başlıklı yazıda Malinof'un iktidara gelişiyle birlikte oluşan benzer endişeler dile getirilmiştir. BOA, HR. SYS. 2456/68, lef.2a. Bulgaristan'da hükümetin kurulma görevinin verilmesinin ardından A. Malinof'un özgeçmişi ve Bulgaristan iç siyasi tarihine, bu meyanda özellikle Bulgar Demokrat Partisi hakkında Osmanlı gazetelerinde haberler yer almıştır. "Malinof Yeni Kabineyi Teşkile Memur”, Tasvir-i Efkar, 19 Haziran 1918, 1, "Malinof'un Tercüme-i Hali”, Sabah, 20 Haziran 1918, 1, “Mösyö Malinof'un Tercüme-i Hali”, Vakit, (20 Haziran 1918), 1, "Bulgaristan Buhranı-Bulgar Demokratları”, Tanin, 22 Haziran 1918, 2. 
Aslında İtilaf Bloku'nda böyle bir endişeyi gösteren önemli işaretler vardı. Öncelikle 1908-1911 tarihleri arasında Başbakanlık yapan A. Malinof, Bulgaristan'ın bir siyasi krizle birlikte Osmanlı Devleti'nden ayrılarak tam bağımsız bir devlet haline gelmesini sağlayan kişi idi. ${ }^{31}$ Özellikle Malinof, Radoslavof gibi İttifak Bloku yanlısı değil, İtilaf Bloku çerçevesinde bir politika takip etmişti. Bu politikasını iktidardan düştükten sonrada devam ettirmişti. Bulgaristan'ın I. Dünya Savaşı'na girmesinden önce de İtilaf Bloku safında savaşa girilmesi taraftarı olduğunu ilan etmişti. Malinof, üç partinin desteğini alan ve İttifak Bloku yanlısı politikalar takip eden Radoslavof Hükümeti'nin iktidarı esnasında, 18 Temmuz 1915'de yaptığı bir konuşmada "düvel-i İtilafiyenin sulhu arzu ettiği surette akdedecekleri netice emri-i aşikârdır. Şu sebeple Bulgaristan galiplerin tarafına geçmesi” gerektiği kanaatini ilan etmişti. Malinof bu konuşmasında, iktidardaki Radoslavof Hükümetinin İtilaf Bloku'nda savaşa dâhil olmasını, Bulgaristan'ı "felakete sevk edecek bir hareket-i serkeştciyane” olarak değerlendirmiş, "düvel-i merkeziye tarafında bulunmağa icbar edecek" her türlü girişimin Demokrat Parti adına karşısında olmuştu. Zira ona göre Almanya ile bir ittifak, üç Balkan devleti (Sırbistan, Yunanistan, Romanya) ve dört büyük devlete (İngiltere, Fransa, Rusya ve İtalya) “düşman”lık ilanı idi. Diğer taraftan Malinof, Bulgaristan'ın savaşa İttifak Bloğu içinde girmesinin ardından ise farklı bir siyasi söylem ortaya koymuştur. Doğrudan doğruya Almanya ile ittifak aleyhinde bir söylem kullanmak yerine, "her vesile zuhur ettikçe” Bulgaristan'ın menfaatinin Radoslavof Hükümetinin takip ettiği politikalarda olmadığını vurgulamıştır. ${ }^{32}$

\section{A. Malinof'un İktidara Gelişinin İttifak Bloku'na Etkisi}

Osmanlı Devleti için Bulgar partilerinin siyasi yaklaşımları, Radoslavof hükümetindeki kriz sonrası iktidara gelen Malinof kabinesinin politikaları, Almanya ve Avusturya-Macaristan'ın sefirleri vasıtasıyla Bulgaristan'da kurduğu ilişkiler önemli idi. Bulgaristan'daki gelişmelerin takibi Malinof Hükümeti ile birlikte daha fazla önem kazanmıştı. Bu noktada Malinof Hükümetinin dış politikada müttefikleriyle kuracağı ilişki ve savaşta takınacağı tavır, endişe ile izlenen bir konu idi. Bu endişe İttifak Bloku'nun geleceğini çok yakından ilgilendirmekteydi.

Başlangıçta yeni Bulgaristan Başbakanı Malinof ve politikalarına dair gelen bilgi ve haberler endişeleri izale edici idi. Bu meyanda Bulgar basınına göre Malinof hükümeti "menafi-i aliye-yi vatan her şeyin fevkinde" tutacak, Bulgaristan'ın çıkarlarının ön plana alacaktı. Bu noktada Malinof hükümeti İttifak Bloku'nu zayıflatmak yerine, aksine daha fazla kuvvetlendirecek, devamını sağlayacaktı. ${ }^{33}$ Yine Avusturya Dışişleri Bakanı Kont

31 Crampton, Bulgaristan Tarihi, 115.

32 Malinof'un siyaseti hakkında bilgi için bk. Hariciye Nezareti'nden Sadarete 15 Temmuz 1918 tarihli yazı, BOA, HR. SYS. 2455/99, lef.1.

33 Sofya Sefaretinden Hariciye Nezaretine 19 Haziran 1918 tarihli yazı, BOA, HR. SYS. 2330/3, lef.1. Malinof'un iktidarı esnasında mevcut dış politikasından "inhiraf" etmeyeceğine, "riayetkâr" davranacağına ve İttifak Bloğuna "sadakat" içinde bulunacağına dair haberler için bk. "Bulgaristan'da Kabine Buhranı", Tanin, 19 Haziran 1918, 1, Yunus Nadi, "Malinof'un Beyanatı", Tasvir-i Efkar, 19 Haziran 1918, 1; "Bulgar Siyasetinde Tebeddül Yok", Sabah, 22 Haziran 1918, 1; "Bulgar Kabinesi”, Vakit, 26 Haziran 1918, 1; Yunus Nadi, "Malinof'un Beyanatı", Tasvir-i Efkar, 10 Temmuz 1918, 1. 
Buryan da, Malinof Hükümeti hakkında benzer kanaate sahip olduğunu Osmanlı Hariciye yetkililerine söylemişti. Hatta Buryan'a göre Malinof, eski başbakan Radoslavof'un politikalarından sapmayacaktı. Zaten Bulgaristan'daki nüfuzuyla her şeye hâkim olan Kral Ferdinand, Bulgar dış politikasında bir sapmaya izin vermezdi. ${ }^{34}$ Nitekim Kral Ferdinand, başbakanlığa Malinof'un atanmasıyla birlikte Bulgaristan'ın dış politikasında bir değişiklik ortaya çıkmayacağını dile getirmişti. ${ }^{35}$

Ancak Malinof'un iktidara gelişi İttifak Bloku içinde, Bulgar-Alman ilişkilerinde ilk sarsıntılarını göstermiştir. Almanya I. Dünya Savaşı boyunca Bulgaristan’ı kendisi için bir hububat ambarı olarak değerlendirmişti. Ancak Bulgaristan'da iaşe, gıda sorunu 1916'dan itibaren şiddetli bir şekilde kendisini göstermekteydi. ${ }^{36} \mathrm{Bu}$ süreçte muhalefette yer alan Malinof, Almanya'nın Bulgaristan'dan büyük oranda hububat alımı yapmasını doğru bulmamaktaydı. Bu noktada Malinof, "yağmakârlık" olarak nitelendirdiği bu satışın Bulgaristan'da hububat yokluğuna neden olacağını ileri sürmüş ve "protesto" etmişti. ${ }^{37}$

Malinof hükümeti, Almanya’ya başka meselelerde de sorun çıkarmıştır. Bulgar Hükümeti, Almanların elindeki tren ve maden imtiyazlarını doğrudan doğruya kendi yönetimleri altına alma ve ithalat ve ihracatta kendi başına hareket etme kararı almıştır. Ayrıca Radoslavof Hükümeti döneminde Almanlara tanınan imtiyazlara ve serbestliğe itiraz eden Eski İaşe Müdürü General Pevotekarof'u tekrar göreve getirilmişti. Bu atama yeni Bulgar Hükümetinin amacını gösterirken, Almanları endişeye sevk etmiştir. ${ }^{38}$

Diğer taraftan Osmanlı Devleti, hükümet değişikliği ile birlikte Bulgaristan'daki "mesail-i siyasiye-yi hariciye hakkındaki işarat-1 mühimme ve aleniyye ile hakayık-1 ahval arasında münasebat" sonucu ortaya çıkacak "asar ve keyfiyet" hakkında kendi sefirinden bilgi istemiştir. Özellikle Malinof'un iktidara gelişi ile birlikte Bulgaristan'ın sulh-i münferit talebinde bulunacağına dair iddialar, Kuzey Dobruca meselesi, yeni Bulgar hükümetinin Müslümanlara takınacağı politika takip edilecek öncelikli konular arasında idi ${ }^{39}$.

Hükümetinin talep ve endişelerini dikkatle takip eden Sofya Sefiri Safa Bey, Malinof'un görüşlerini öğrenmek için bizatihi kendisi ile uzun bir görüşme yapmıştır. Bu çerçevede Malinof Hükümeti ve Bulgaristan'daki gelişmeler hakkında Osmanlı Hariciye Nezaretine detaylı bilgi sunmuştur. Safa Bey, Malinof'un iktidara geldikten sonra "selefi gibi harici

34 Viyana Sefaretinden Hariciye Nezaretine 20 Haziran 1918 tarihli telgraf, BOA, HR. SYS. 2330/4, lef.1; Hariciye Nezaretinden Berlin Sefaretine 27 Haziran 1918 tarihli şifre telgraf, BOA, HR. SYS. 2330/4, lef.2. 18 Haziran 1918 tarihli Külnirche Beitung/Kölnijche Çanyung gazetesine göre Malinof’un iktidara gelişiyle birlikte Bulgar dış politikasında bir değişimin beklenmesi doğru değildi. Hariciye Nezaretinden Sadarete 25 Haziran 1918 tarihli yazı, BOA, HR. SYS. 2454/74, lef.1. Kral Ferdinand'ın Bulgaristan'daki etkisi ve dış politikada İttifak yanlısı tavırları için bk. "Radoslavof'un Halefleri de Aynı Siyaseti Takip Edeceklermiş", Tasvir-i Efkar, 22 Haziran 1918, 2: "Malinof Kabinesi”, Ati, 22 Haziran 1918, 1.

35 Bulgaristan Kralı Ferdinand'ın Sultan Reşat'a çektiği 23 Haziran 1918 tarihli telgrafın tercümesi, BOA, HR. SYS. 2330/7, lef.1.

36 Crampton, Bulgaristan Tarihi, 121-127.

37 Hariciye Nezaretinden Sadarete 15 Temmuz 1918 tarihli yazı, BOA, HR. SYS. 2455/99, lef.1.

38 Sofya Sefaretinden Hariciye Nezaretine 4 Temmuz 1918 tarihli yazı, BOA, HR. SYS. 2455/51, lef.1.

39 Hariciye Nezaretinden Sofya Sefaretine 30 Haziran 1918 tarihli şifre telgraf, BOA, HR. SYS. 2455/35, lef.1. 
siyasette berdevam" olacağını resmen ilan ettiğini Almanya, Avusturya-Macaristan ve Osmanlı Sefirleriyle ilişkisini, "münasebet-i zahiresi” doğal olarak değerlendirmişti. Safa Bey, başlangıçta Malinof Hükümeti'nin dış politikasında "şimdilik dai-i şüphe” bir durum görmemişti. Ancak ihtiyatlı yaklaşmış ve gelecekte ne olacağını kestirmek, kesin bir fikre sahip olmak için "vaktin" erken olduğu kanaatinde idi"

$\mathrm{Bu}$ görüşmede Osmanlı Sefiri, Türk-Bulgar ilişkilerinde olumsuzluk oluşturan Makedonya' da Müslüman ahaliye karşı yapılan “mezalime” dair bir “muhtırayı” da Malinof'a sunmuştur. Sefa Bey’e göre bu muhtıra Malinof tarafından "hüsn-i telakki” ile karşılanmıştı. Görüşmede Malinof “derhal” inceleyeceğini ve zulüm uygulamaları mevcut ise son verilerek suçluların cezalandırılacağını ifade etmişti. Malinof'un bu tavrı Safa Bey üzerinde olumlu bir intiba bırakmıştır. Sefa Bey açısından Malinof kabinesi, Radoslavof hükümetine göre daha "kanunperest" idi. Bu yüzden Makedonya'da Müslümanlara "reva görülen mezalime" son verileceğini ümit etmekteydi ${ }^{41}$.

Ancak Malinof'un Safa Bey’e verdiği beyanlara rağmen Osmanlı-Bulgar ilişkilerinde olumsuzluklar, güvensizlikler ve endişeler devam etmiştir. Bunların başında toprak tavizine ve Bulgarların tek başına İtilaf Devletleriyle barış imzalayacağına dair endişeler gelmekteydi. $\mathrm{Bu}$ endişeler İttifak Bloğunda bölünmelere neden olmuştu. Bu sorunlardan biri olan toprak tavizleri hususu Malinof’un başbakanlığından önce Osmanlı-Bulgar ilişkilerini sarsmıştı.

\section{Aleksander Malinof Hükümetinin Kurulmasının Osmanlı-Bulgar İlişkilerine Etkisi}

Malinof'un iktidara gelişi ile birlikte Osmanlı Devleti açısından olumsuzluklar taşıyan ve müttefikliğe uymayan ilk tavırlar ortaya çıkmıştır. Bu meyanda Osmanlı sınırına çok yakın ve İtilaf cephesine uzak bir mevki olan Cisr-i Mustafapaşa civarına Bulgarlar asker yığmış ve yeni istihkâmlar inşa etmişti. Ayrıca bu bölgede bulunan Bulgar ordusundaki Türkler başka mahallere sevk edilmiş ve askeri birliklerde sadece Bulgarlar bırakılmıştır ${ }^{42}$. Yine Bulgar makamları, Osmanlı Devleti tarafından Bulgaristan'a terk edilen Karaağaç'a Edirne'den askeri geçişleri 6 Temmuz 1918'den itibaren zorlaştırmaya çalışmıştır. 1915 sınır düzenlemesi antlaşmasına aykırı olarak sınır geçişlerinde Bulgaristan'ın Edirne Konsolosluğunun onaylı belgesi şartı getirilmişti ${ }^{43}$.

40 Sofya Sefaretinden Hariciye Nezaretine 4 Temmuz 1918 tarihli yazı, BOA, HR. SYS. 2455/51, lef.1.

41 Sofya Sefaretinden Hariciye Nezaretine 4 Temmuz 1918 tarihli yazı, BOA, HR. SYS. 2455/51, lef.1.

42 Filibe Başşehbenderliğinden alınan telgrafa istinaden Sofya Sefaretinden Hariciye Nezaretine 4 Temmuz 1918 tarihli telgraf, BOA, HR. SYS. 2455/52

43 Osmanlı 2. Kolordusu yetkililerine göre Bulgarların onaylı belge uygulaması 1915 sınır düzenlemesine dair antlaşmaya aykırı idi. Zira Karaağaç’ın Bulgarlara terkinde Osmanlı Devleti ile Bulgaristan arasında “tanzim ve teati edilen protokol" gereğince "cihet-i askeriyece Karaağaç cadde ve istasyonundan bilakaydüşart istifade" edilmesi kabul edilmişti. Bu protokol hala yürürlükte idi. Osmanlı makamları Bulgaristan’ın bu uygulamasının devam etmesi halinde, “mukabele-i bilmisl” olmak üzere Karaağaç’taki Osmanlı Şehbenderliğinin Bulgarlardan onaylı belgesi istemesini uygun olacaktı. Osmanlı Orduyu Hümayun Başkumandanlığı Vekâleti’nden Hariciye Nezaretine 17 Ağustos 1918 tarihli yazının sureti BOA, Hariciye Nezareti İdare (HR. İD.) 87/40, lef.1-2 


\subsection{Dünya Savaşı’nda Osmanlı-Bulgar İlişkilerinde Önemli Bir Sorun: Toprak Tavizleri}

1918 yılındaki bazı gelişmeler İttifak Bloku'nda tereddüt ortaya çıkarmış, dolayısıyla Osmanlı Devleti ile Bulgaristan arasındaki sorunları daha ciddi ve müttefikliğe zarar verecek olumsuz bir noktaya taşımıştır. 1918 yılı başındaki bu tereddüt ve olumsuzluklar, Brest-Litovsk Antlaşması ve İtilaf Bloku'ndaki Romanya'nın savaş dışına itildiği, İttifak Devletlerinin önemli başarılar ve kazanımlar elde edildiği bir dönemde ortaya çıkmıştı. Zira İttifak Devletleri elde ettikleri kazanımlar ve toprak paylaşımında anlaşmazlığa düşmüşlerdi. Brest-Litovsk Antlaşması'yla Rusya'nın savaştan çekilmesi ve Karadeniz'deki askeri faaliyetlerine son vermesi Osmanlı-Bulgar ilişkilerinde olumsuzluklar ortaya çıkarmıştı. Brest-Litovsk Antlaşması'na göre Osmanlı Devleti Kafkasya'da bazı haklar elde ettiği gibi Karadeniz'deki Rus donanmasının paylaşımında pay sahibi olmuştu. Bu noktada Bulgaristan kamuoyu ve siyasetçileri Rus donanmasının paylaşımında Osmanlı Devleti lehine daha fazla avantajlar verileceğine dair haberlerden rahatsızlardı. Karadeniz ve Rus donanması meseleleri yüzünden Bulgar kamuoyunda "şiddetli” itirazlar vard1 ${ }^{44}$.

Ancak asıl sorun alanı İtilaf Devletleri safında savaşa dâhil olan Romanya'nın topraklarının paylaşımı sürecinde yaşanmıştır. Alman, Avusturya-Macaristan, Bulgar ve Osmanlı orduları tarafından tamamen işgal edilen Romanya, 7 Mayıs 1918'de imzalanan Bükreş Barış Antlaşması ile savaş dışı bırakılmıştı. Bu görüşmeler sürecinde Bulgarlar öncelikle II. Balkan Savaşı'nda kaybettikleri Romanya'nın kontrolündeki Kuzey Dobruca bölgesini kendi topraklarına katmak istemişlerdi. Aslında sadece Bulgarlar Kuzey Dobruca'da değil, İttifak Güçleri'nin işgal ettiği Makedonya'da da taleplerinin karşılanmamasından rahatsızlar idi. Osmanlı Devleti ise Bulgaristan'ın bu toprak kazanımlarına karşılık 1915 Mayıs'ında Meriç boyunca terk eylediği arazinin iadesini, Edirne'nin istasyonu ve ekonomik kapısı olan Karaağaç’ın iadesini talep etmişti. Sınır düzenlemelerini içeren bu talepler Tavizât şeklinde adlandırılmıştı. Hatta bu taviz taleplerine dair haberlerde Dedeağaç şehri de basına yansımıştı. Osmanlı Devleti, bu tavizlerde Almanya ve Avusturya'nın desteğini almaya çalışmıştır ${ }^{45}$.

44 Hariciye Nezaretinden Sadarete 15 Temmuz 1918 tarihli yazı, BOA, HR. SYS. 2455/99, lef.1. Osmanlı Orduyu Hümayun Başkumandanlı̆̆ı Vekâleti'nden Hariciye Nezaretine, Emniyet-i Umumiye Müdüriyeti, Sofya Ateşemiliterliğine, 5. Ordu Kumandanlığına, 1. Kolordu Kumandanlığına 15 Eylül 1918 tarihli yazı, BOA, HR. SYS. 2327/7, lef.1-2. Tasvir-i Efkâr gazetesinde Karadeniz ve Rus donanması hakkında çıkan makaleler Bulgaristan'da eleştirilmiş ve sert tepki verilmiştir. Zira Rus donanmasının Osmanlı Devleti'ne terki hususunda ortaya konulan değerlendirmeler Bulgarların "hissiyatlarını tahrik" etmiştir. Bazı Bulgar gazeteleri II. Balkan Savaşı'nda Bulgaristan'ın yaşadıkları akıbeti hatıllatmışlardır. Sofya Sefareti'nden Hariciye Nezaretine 16 Mayıs 1918 tarihli yazının sureti, BOA, Sadaret Eyalet-i Mümtaze Bulgaristan Evrakı (A.\} MTZ.) (04) 175/56, lef.2. Rusların Karadeniz'deki donanmasııın akıbetine dair Osmanlı basınında çıkan bazı haber ve yorumlar için bk. "Filo Bulgaristan'a Verilmeli", Zaman, 17 Haziran 1918, 3; "Karadeniz Filosu”, Tanin, 21 Mayıs 1918, 1; “Karadeniz Filosu”, Tanin, 23 Mayıs 1918, 1; Ahmet Emin, "Karadeniz Filosu ve Almanya", Vakit, 25 Haziran 1918, 1

45 Berlin'deki Tagliche Rundschau gazetesinin Viyana muhabirinin 30 Nisan 1918 tarihlinde yayınlanan mektubunun tercümesi, BOA, A.\} MTZ. (04) 175/53, lef.1; Osmanlı Ordu-yu Hümayunu Başkumandanlı̆̆ı Vekâleti'nden Hariciye Nezaretine 13 Ağustos 1918 tarihli yazı (Lahey Ateşemiliterliğinden Osmanlı Ordu-yu Hümayunu Başkumandanlığı Vekâleti'ne gönderilen telgrafin sureti) BOA, HR. SYS. 2457/44, lef.1 
Tavizata dair yapılan görüşmeler esnasında Bulgar heyeti adına (Tançef) başlangıçta çekimser davranmış idi. Ancak Alman Hariciye Nazırı Von Kolman sayesinde talep Sofya’ya iletilmiştir. Sofya Sefiri Safa Bey’e göre Bulgaristan’a gelen Alman Dışişleri Bakanı Von Kolman, Radoslavof'a bir “nota” vermişti. Bu notada, Kuzey Dobruca'nın Bulgaristan'a bırakılmasını, Almanya ile bazı ekonomik sorunların ve Osmanlı Devleti ile "tavizat"ın çözümlenmesi şartına bağlanmıştı ${ }^{46}$. Radoslavof kabinesi başlangıçta Balkanlarda Bulgarların gelecekte kazanacakları topraklara karşılık Türkiye'nin yeni tavizlerde bulunmaması şartıyla Alman teklifini kabul etmişti. Ancak Bulgar makamlarına göre, Osmanlı Devleti bu tür bir şarta rıza göstermeyecekti. Zira Bulgaristan'ın Makedonya ve Morava'ya doğru yeni genişlemeler, topraklar alması halinde, Osmanlı Devleti de Meriç'in sağ cihetinde ve deniz sahilindeki Dimetoka ve Gümülcine ile beraber geniş bir coğrafyanın “iadesini” talep edecekti. Bulgar siyasetçileri bu durumdan oldukça rahatsı idi ${ }^{47}$.

Ancak Bulgar hükümeti ve kamuoyunda tavizler hususunda ciddi bir direnç söz konusuydu. Üstelik Bulgar taleplerinin gerçekleşmesinin Osmanlı Devleti lehine tavizlere bağlı kılınmasından ve Almanya'nın bu yönde politikası ve baskısından rahatsızlık vardı. Nitekim Doğu Makedonya, Kuzey Dobruca, Meriç sorunlarının Bulgaristan'ın istediği gibi çözümlenmemesinin yanı sıra Almanlara önemli miktarda hububat ihraç edilmesi, yukarıda ifade edildiği üzere İttifak yanlısı Radoslavof başkanlığındaki Bulgar hükümetini iç politikada zor duruma düşürmüştü. Ayrıca kamuoyu ve siyasi sahnenin önemli oluşumları hükümet ile aynı fikirde değildi. Muhalif partiler bu olumsuz havadan istifade etmişler ve mecliste güçlü olmayan Radoslavof Hükümetinin çoğunluğu kaybetmesine neden olmuşlard1 ${ }^{48}$.

Bulgar siyasetçileri ve kamuoyu tavizlerin Osmanlı Devleti’nin "arzu” ettiği şekilde çözümlenmesine, eskiden beri olduğu üzere hiçbir şekilde taraftar değildi. Hatta bu hususta bütün Bulgar basınında "fırsat düştükçe” Osmanlı aleyhinde makaleler kaleme alınmaktaydı. Bulgarlar, sürecin II. Balkan Savaşı'nda olduğu gibi kendi aleyhlerine gelişeceği düşüncesindeydiler. Bu yüzden Kuzey Dobruca ile ilgili tartışmalar sürecinde Bulgar siyaseti ve basını rahatsızlıklarını en üst seviyede hissettirmişlerdi. Bu meyanda Bulgaristan' daki yarı

46 Sofya Sefaretinden Hariciye Nezaretine 26 Mayıs 1918 tarihli yazının sureti, BOA, A.\} MTZ. (04) 175/58, lef.2; Osmanlı Orduyu Hümayunu Başkumandanlığı Vekâleti'nden Hariciye Nezaretine 13 Ağustos 1918 tarihli yazı BOA, HR. SYS. 2457/44, lef.1. Kalinise Caniburg gazetesinin 16 Mayıs 1918 tarihli "Türkiye ve Bulgaristan" başlıklı yazısının tercümesinde aşağıdaki hususlar öne çıkarılmıştı: Romanya ile yapılan muahede Dobruca'nın kuzey kısmı yönetiminin düvel-i erbaanın ortaklığına bırakılmıştır. Bu şekilde bir yol takip edilmesi müttefikler ve özellikle Türkiye-Bulgaristan arasındaki bazı meseleler henüz halledilmemişti. Osmanlı Devleti Bulgaristan'a karşı savaş sırasında güvensizlik oluşturacak bir harekette bulunmamıştı ve bu siyasetini devam ettirmekteydi. Zaten Kafkasya Cumhuriyetiyle kurulacak yakın ilișkilerin Osmanlıların Asya'daki topraklarında "tekamülat-1 atiyesine" yeni yeni yollar açacaktı. BOA, A.\} MTZ. (04) 175/59, lef.1; "Murahhasların Avdeti”, Tanin, 9 Mayıs 1918, 3381, 2.

47 Osmanlı Ordu-yu Hümayunu Başkumandanlığı Vekâleti'nden Hariciye Nezaretine 13 Ağustos 1918 tarihli yaz1, BOA, HR. SYS. 2457/44, lef.1

48 İstanbulistlerin Malinof Başkanlığındaki Demokrat Partisi'ni desteklemesi halinde Radoslavof Hükümeti düşebilirdi. Külnirche Beitung/Kölnijche Çanyung gazetesinin 18 Haziran 1918'deki nüshasındaki yazının tercümesi, Hariciye Nezaretinden Sadarete 25 Haziran 1918 tarihli, BOA, HR. SYS. 2454/74, lef.1 
resmî bir gazetedeki “Cihan Harbi ve Meriç'in Mecra-yı Süflası” başlıklı yazısında 1915'de Bulgaristan'a terk edilen yerlerin iadesi Bulgarların "selamet-i emniyetine" uygun değildi ${ }^{49}$. Bulgarların tavizler hususunda Osmanlı Devleti aleyhine direnci, karşılık bulmuştur. Almanya'daki bazı gazetelerde Bulgarları haklı gösteren yazılar kaleme alınmıştır ${ }^{50}$.

Diğer taraftan yukarıda ifade edildiği üzere Bulgar resmî makamları Radoslavof'un istifasını ve Malinof'un Başbakanlığa getirilmesini iç siyasi, iktisadi hususlarla izah etmişlerdi. Ancak Osmanlı basınına göre istifa ve Malinof'un başbakanlığa getirilmesi, İttifak Devletlerince Bulgarların taleplerinin Kuzey Dobruca'da yerine getirilmemesinden kaynaklanmıştı. Bu meyanda tavizkâr bir tutum içinde olduğu düşünülen, en azından görüşme masasından ayrılmayan Radoslavof yerine, Malinof'un Kuzey Dobruca meselesinde sertlik ve ödün vermez bir siyasi politika yanlısı tavrı başbakanlığa yürüyüşünün altında yatan önemli sebepler arasında gösterilmiştir. Osmanlı basını Kuzey Dobruca üzerinden yaşanan Meriç tartışmalarının Malinof'un başbakanlığı döneminde ve takınacağı politikalar nedeniyle derinleşmesinden endişe etmekteydi ${ }^{51}$.

$\mathrm{Bu}$ süreçte Osmanlı basını, Osmanlı Devleti'nin sınır düzenlemeleri yönündeki taleplerini haklı gösterecek yazılar kaleme almışlardır. Bu haklılık meyanında Meclis-i Mebusan İkinci Reisi Hüseyin Cahit Bey’in beyanatı, Edirne Mebusu Faik Bey’in gazetelere verdiği mülakat gazete sütunlarına taşınmıştır. Yine Ati gazetesinde Celal Nuri Bey Kuzey Dobruca ve Besarabya karşılığında Mesta ve Usturuma vadilerini talep eden bir yazı kaleme almıştı ${ }^{52}$. Hüseyin Cahit Bey'in beyanatı ve Osmanlı basınının bu tür bir yazı politikası takip etmesi, Bulgar matbuatıyla sert atışmalara, "asabiliklere" neden olacak bir süreci de başlatmıştır. Bulgar gazeteleri ise Bulgaristan’ın "Meriç gibi bir meselesinin” olmadığını

49 Osmanlı makamlarına göre gazetede çıkan bu yazı Bulgar hükümetinin görüşlerini yansıtmaktaydı. Bulgar hükümeti bu yazı ile Osmanlı Devleti'nin taleplerinin önünü almak istemişti. Sofya Sefaretinden Hariciye Nezaretine 26 Mayıs 1918 tarihli yazının sureti, BOA, A.\} MTZ. (04) 175/58, lef.2; Osmanlı Orduyu Hümayunu Başkumandanlığı Vekâleti’nden Hariciye nezaretine 13 Ağustos 1918 tarihli yazı, BOA, HR. SYS. 2457/44, lef.1.

50 Gazetede çıkan yazı şu şekilde değerlendirilmiştir: “güya mazlum Balkan devleti haline gelmiş Bulgaristan'ın denizde büyük bir sahile malik olması icab eylediğinden bahisle Bulgarların Dedeağaç limanına şedid ihtiyaçları olduğunu zikretmeleri Bulgarlara tavizat hususundaki teklifatımızı red ve cerh eylemek için bir takım delail-i cedide bahşetmekte ve bu halin binnetice bize karşı Bulgarların lisan-1 tecavüzünü uzatmağa sebep olmaktadır. Alman neşriyatına Alman hükümetine mensup bazı ricalin teşvik ve talimatı dairesinde cereyan etmekte veyahut ceraid-i mezkurenin Bulgarlarca satın alınmış olunmasına kani olmak lazım gelmektedir. Neşriyata mani olacak tedbirlere başvurulması veya bazı Alman gazeteleriyle hukuk-1 meşruamızı müdafaa etmeliyiz." Sofya Sefareti'nden Hariciye Nezareti'ne 16 Mayıs 1918 tarihli yazının sureti, BOA, A.\} MTZ. (04) 175/56, lef.2.

51 "Bulgar Diplomatının Beyanatı Münasebetiyle", Sabah, 22 Haziran 1918, 1; "Radoslavof Kabinesinin İstifası Münasebetiyle Garbi Trakya Meselesi”, Ati, 18 Haziran 1918, 2. Radoslavof Hükümetinde bakanlık yapan İstanbulist Fırkasına Mensup Kişilerin istifa gerekçesi kabinedeki Kuzey Dobruca nedeniyle ortaya çıkan fikir ayrılığı idi. Ahmet Emin, "Bulgar Başvekilin İstifası", Vakit, 18 Haziran 1918, 1; "Bulgaristan’da Kabine Buhranı”, İkdam, 20 Haziran 1918, 1; "Yeni Bulgar Kabinesi ve İstanbulivistler”, Tanin, 19 Temmuz 1918, 2. Ayrıca Osmanlı basınında Malinof Kabinesinin Türkiye ile ilgili takip edeceği söylemler Radoslavof döneminde çözülemeyen sorunlara dair beklentiler mevcuttu. "Bulgar Kabine Buhranı”, Tanin, 24 Haziran 1918, 1.

52 Hüseyin Cahit, "Harbden Sonra Bulgaristan", Vakit 17 Haziran 1918, 1; "Bizce Meriç Değil Garbi Trakya Meselesi”, Ati, 17 Haziran 1918, 1; "Meriç Meselesi ve Bulgar Matbuatı", Tanin, 20 Haziran 1918, 1 "Meriç Meselesi", Tasvir-i Efkar, 22 Haziran 1918, 2; "Meriç Meselesi”, Sabah, 22 Haziran 1918, 1. 
daima tekrarlamışlardır. Her iki basın da Kuzey Dobruca-Meriç meseleleri üzerinden siyasi ortamın sertleşmesinden ve gerginleşmesinden birbirlerini suçlamışlardır. Osmanlı ve Bulgar gazeteleri Dobruca ve Meriç meselesini basit bir toprak parçası olarak değerlendirmemişler, milli bir hassasiyetle ve devletlerinin stratejisi ile ilişkilendirmişlerdir ${ }^{53}$.

\subsubsection{Malinof'un Tavizat Meselesine Bakıșı}

Malinof Hükümeti iktidara geldiğinde, Osmanlı Devleti ile Bulgaristan arasında tavizat konularını da içeren Brest-Litovsk Antlaşması, Bükreş Antlaşması ve Kuzey Dobruca topraklarının paylaşımı konularından kaynaklanan sorunlar devam etmekteydi. Malinof tavizat ve toprakların paylaşımına dair görüşlerini, iktidarda olmadığı bir tarihte, Ocak 1918'de kesin bir şekilde belli etmişti. Malinof, 30 Ocak 1918'de Sobronya'daki konuşmasında, Almanya'nın Bulgaristan'dan bazı tavizler talep etmesini ve Brest-Litovsk Antlaşmasını eleştirmişti. Malinof bu memnuniyetsizliğini "Bulgaristan kendi menfaatinin müttefiklerce bu vecihle telakki edileceğini akdemce hissetmiş olsa idi, bugün bulunduğumuz tarafta olmayacağımızı müttefiklerimize anlatmaya sahip olmalı idi” sözleriyle çok açık bir şekilde dile getirmiştir ${ }^{54}$.

Malinof tavizler hususundaki tavrını iktidara gelmesinden sonra da sürdürmüştür. Malinof, Safa Bey ile yaptığı görüşmede Kuzey Dobruca sorununda "gayri mevcut” gibi davranmış, "tashihi-i hudud" konusunda yakınlık, dostluk göstermemiş ve hatta Radoslavof Hükümetinden "daha 1srarcı" olmuştur ${ }^{55}$. Başbakan Malinof birçok kez gazetelere verdiği beyanatta, Bulgaristan'ın Meriç meselesi olmadığını, aksine Osmanlı-Bulgar sınırının 1915' de imzalanan antlaşmayla çözümlendiğini sürekli vurgulamıştır. Ayrıca Dobruca'da Bulgaristan aleyhine haksızlıklar yapıldığını ifade etmekten çekinmemiştir ${ }^{56}$. Malinof'un bu tavrı, yani tavizat konusunu yok sayarak hareket etmesi, Osmanlı-Bulgar ilişkilerine, dolayısıyla İttifak Bloku'nu bütünlüğüne zarar verecek bir durum ortaya çıkarmıştır. Almanya ve AvusturyaMacaristan Devletleri, Bulgaristan politikalarını gözden geçirmek zorunda kalmıştır.

Nitekim yukarıda ifade edildiği üzere 1918 Haziran'ında İttifak Bloku'nda, Bulgaristan'ın dış siyasetinde bir değişiklik beklenmemesine rağmen, Temmuz ayından itibaren Alman ve

53 "Bizce Meriç Değil Garbi Trakya Meselesi”, Ati, 17 Haziran 1918, 1; "Meriç Meselesi-İki Bulgar Gazetesinin Makaleleri”, Sabah, 17 Haziran 1918, 1; "Garbi Trakya Meselesi-Preporiç Gazetesi İle Ati”, Ati, 20 Haziran 1918, 1; "Bulgar Gazeteleri”, Sabah, 21 Haziran 1918, 1; "Meriç Meselesi Hakkında-Nim Resmî Bulgar Gazetesinin Makalesi”, Sabah, 24 Haziran 1918, 1; "Garbi Trakya Meselesi-Bulgar Matbuat Coşmuş”, Ati, 30 Haziran 1918, 3; "Meriç meselesi Hakkında Mülakat”, Tasvir-i Efkar, 26 Haziran 1918, 2; "Meriç Meselesi ve Bulgaristan", Sabah, 2 Temmuz 1918, 1; "Meriç Meselesi ve Bulgar Matbuatı", Tanin, 2 Temmuz 1918, 2; Meriç Meselesi Var Mi Yok Mu?”, Tasvir-i Efkar, 3 Temmuz 1918, 1.

54 Hariciye Nezaretinden Sadarete 15 Temmuz 1918 tarihli yaz1, BOA, HR. SYS. 2455/99, lef.1.

55 Sofya Sefaretinden Hariciye Nezaretine 4 Temmuz 1918 tarihli yazı, BOA, HR. SYS. 2455/51, lef.1.

56 “Malinof'un Beyanatı", Tasvir-i Efkar, 10 Temmuz 1918, 1; "Malinof'un Beyanat1-Türkiye ile Hudud Meselesi Yokmuş", Sabah, 12 Temmuz 1918, 1. "Malinof'un Beyanat1-Bulgaristan ve İttifak Devletleri-Dobruca ve Meriç Meselesi”, Sabah, 29 Temmuz 1918, 1; "Dobruca ve Meriç Meseleleri-Malinof'un Yeni Beyanatı", Tanin, 23 Ağustos 1918, 2. 
Avusturya-Macaristan politikacılarının endişe içinde olduklarını söylemek mümkündür. $\mathrm{Bu}$ noktada Safa Bey, Malinof'un iktidara gelişiyle birlikte Almanya ve Avusturya-Macaristan'ın tavizat hususunda bir politika değişikliğine gitmeye çalıştıklarına dair bir sinyal verdiklerini fark etmiştir. Çünkü kısa bir süre için ülkelerine dönen Almanya ve Avusturya-Macaristan'ın Sofya sefirleri büyük ihtimalle, tavizat meselesinde Malinof kabinesine "tazyik" yapılmasını "tehlikeli” bulduklarını kendi hükümetlerine "telkin" edeceklerdi. Safa Bey, bu politika değişikliğini, Almanya ve Avusturay-Macaristan'ın Bulgaristan'1 kaybetmemek adına tavizat meselesinde Osmanlı Devleti lehindeki siyasetlerini terk etmek olarak değerlendirmiştir. Zira Almanlar ve Avusturyalılar, Malinof kabinesinin dış politikada değişikliğine gitmesinden korkmaktaydılar. Bu yüzden İttifak Bloku içinde, artık tavizat konusunun gündeme gelmesini istememişlerdi. Bu noktada Safa Bey’e göre Osmanlı Devleti aleyhine oluşan bu yeni havanın, "telkinatın" sonuçsuz bırakılması için her türlü çaba sarf edilmeliydi ${ }^{57}$. Nitekim bu çerçevedeki sorunların “dostane” bir şekilde çözümü için Osmanlı Kabinesi Sadrazam Talat Paşa'nın Berlin ve Viyana’ya seyahatini ve müttefikleri Almanya ve Avusturya-Macaristan'ın “tavassutunu” uygun görmüştür ${ }^{58}$.

Böylece Malinof ile İttifak Bloku arasındaki temel sorunlardan biri bariz bir şekilde ortaya çıkmıştı. Bu sorunu Malinof'a yakın olan Mir gazetesi de sütunlarına taşımıştır. Gazeteye göre Bulgaristan'ın müttefiklerle ilişkilerini “metin bir esasa rabt” etmek isteyen Malinof'un Berlin ve Viyana'ya gitme ihtimali vardı. Bu başkentlerdeki gündemin en önemli maddesi, Osmanlı Devleti ile Bulgaristan arasındaki "tavizat meselesi" olacaktı. Gazeteye göre Malinof'un tavizat hususunda "müsaadekâr" bir tavır benimsemesi mümkün değildi. Hatta Bulgaristan'ın müttefiklerinin 1srarcı olmaları halinde, İttifak Bloğu'nda bir "tehlike" ortaya çıkması ihtimal dâhilinde idi ${ }^{59}$.

\subsection{Bulgaristan'ın İtilaf Devletleriyle Tek Başına Barış Yapma İddiaları: Sulh-i münferid}

I. Dünya Savaşı'nda bütün imkânlarını kullanan her iki blok, savaşın getirmiş olduğu iktisadi, siyasi ve askeri ağırlığı altında zorlanmaktaydılar. Savaşın son yılında muhasım her iki blok içinde sulh arayışlarını görmek mümkündür. Bu sulh arayışlarına giren ülkelerden biri

57 Sofya Sefaretinden Hariciye Nezaretine 4 Temmuz 1918 tarihli telgraf, BOA, HR. SYS. 2455/55, lef.1. Hatta Almanya sefiri bu meselenin Radoslavof zamanında hal edilmeyip sürüncemede bırakılmasına teessüf etmişti. Nitekim Osmanlı makamlarının ve Safa Bey’in endişelerini haklı çıkaracak beyanatlar Alman Bürokrasisinden verilmişti. Alman Bakan Von Kolman, Dobruca meselesinde Türk-Bulgar anlaşmazlığında Almanya'nın her iki ülkeye de eşit mesafede olduğunu beyan etmiştir. "Meriç Meselesi Hakkında”, Sabah, 16 Haziran 1918, 1; "Von Kolman'ın Nazariyesi”, Sabah, 24 Haziran 1918, 1; “Türkiye-Bulgaristan İhtilafi- Alman Hariciye Nazırının İzahatı", Tasvir -i Efkar, 27 Haziran 1918, 1; "Von Kolman'ın Nutku”, Ati, 27 Haziran 1918, 1; “Türkiye ve Bulgaristan Arasındaki Mesail”, Tanin, 6 Temmuz 1918, 4.

58 Bulgaristan'ın sulh faaliyeti ve tutumu hakkında 20 Ağustos 1918 tarihli tutulan müsvedde, BOA, HR. SYS. 29807/90, lef 1-2.

59 Mir, Malinof'un politikalarının “naşir-i efkarı” olan Preporeç(?) gazetesinde yazılamayanların neşredildiği bir gazete idi. Sofya Sefaretinden Hariciye Nezaretine 4 Temmuz 1918 tarihli yazı, BOA, HR. SYS. 2455/51, lef.1. 
de Bulgaristan idi. Hatta Bulgaristan'ın İtilaf Devletleriyle tek başına barış yapacağına dair haberler basın ve siyasi çevrelerde dillendirilmekteydi. Özellikle Malinof'un iktidara gelişi bu tür haberlerin artmasına yol açmıştı. Malinof, Safa Bey ile Temmuz ayı başındaki yaptığı görüşmede, "artık sulhun akdine şayan-1 temenni olunduğuna" dair bazı ifadeler kullanmıştı. Ancak Safa Bey, Malinof'un bu ifadelerini “sulh-i münferid akd taraftarı olduğu” şeklinde değerlendirilememişti ${ }^{60}$. Malinof ve çevresinin taraftarlığını yapan gazeteler de yukarıda ifade edildiği üzere başlangıçta Bulgaristan'ın İttifak Bloku’ndan ayrılacağı ve barış isteyeceğine dair "şayiaları" yalanlamışlardı ${ }^{61}$.

Ancak kısa bir süre sonra Safa Bey’in düşüncelerinde bir tereddüt halini, zihnindeki karışıklığı görmek mümkündür. Safa Bey’e göre başlangıçta Malinof, İttifak Bloku lehinde beyanlarda bulunmuş ve olumlu bir hava oluşturmuştu. Bununla birlikte Radoslavof hükümetinin iktidardan düşürülmesi sürecinde, yani Başbakan olmadan önce Malinof ve taraftarları, İttifak Bloku açısından olumsuz propagandalarda da bulunmuşlardı. Bunların başında, iktidara gelmeleri halinde "iki buçuk aya kadar" barış yapacaklarına dair Malinof'un Bulgar ordusuna söz verdiği propagandası idi. Bulgaristan siyasi çevrelerinde dolaşan bu propagandalar söylenti şeklinde, hatta Malinof'a yakın gazeteler tarafından yalanlanmış olsa da Bulgar ordusunu etkilediği kesin idi' ${ }^{62}$. Nitekim Ağustos 1918 başlarında Malinof kabinesinin "tebdil-i siyaset ederek bir sulh-i münferid" yapacağına dair "rivayetler" artmaya başlamıştı. Safa Bey rivayetleri onaylayacak "ciddi” "emare”, delil elde edememişti. Ancak söylenti de olsa, bu tür rivayetlerin Bulgar ordusunda kötü bir tesir meydana getirdiği aşikârdı. Safa Bey, bu tür rivayetlerle ilgili olarak Bulgaristan'daki Alman ve Avusturya-Macaristan sefirleriyle de görüşmüştür. Alman ve özellikle Avusturya-Macaristan sefirine göre, Bulgar ordusu içinde "ufak tefek bazı yolsuzluklar" vardı. Ancak Malinof hükümetinin İtilaf Bloku ile "münferid" bir barış antlaşması imzalamalarını imkân dışı görmüşlerdi.

Ancak Safa Bey elde ettiği bilgilere istinaden Bulgaristan'ın "gayet nazik” bir süreçten geçtiğinin farkındadır. Öncelikle Bulgar ordusunda sulh için yapılan propagandalar olumsuz etkiler meydana getirmişti ve uzun müddet "mukavemet ve harbe devam” hissi ve düşünceleri sarsılmıştı. Öyle ki bu süreçte küçük bir kıvılcımın büyük bir "gaile”ye dönüşmesi mümkündü. Ordunun dışında kamuoyunda da barış istekleri mevcut idi. Nitekim Ağustos-Eylül 1918'de "sulh-i münferid" "rivayetleri" Bulgar ordusundaki barışa dair beklenti ve arzuları arttırmıştı. Hatta bu rivayet ve beklentilerin Bulgaristan ordusunda gevşeklik yaşanmasına ve bozuklukların oluşmasına neden olmuş ve 15 Eylül 1918'de Makedonya' daki İtilaf ordularının genel saldırısis ${ }^{63}$ karşısında Bulgar güçlerinin tutunamamanın önemli bir sebebi olarak gösterilmişti ${ }^{64}$

60 Sofya Sefaretinden Hariciye Nezaretine 4 Temmuz 1918 tarihli yazı, BOA, HR. SYS. 2455/51, lef.1.

61 Sofya Sefaretinden Hariciye Nezaretine 11 Ağustos 1918 tarihli şifrenin sureti, BOA, HR. ŞFR (04) 287/79, lef.1-2.

62 Sofya Sefaretinden Hariciye Nezaretine 11 Ağustos 1918 tarihli şifrenin sureti, BOA, HR.ŞFR (04) 287/79, lef.1-2.

63 Birinci Dünya Harbi, Avrupa Cepheleri (Makedonya Cephesi), 7/3, s.68; Yusuf Hikmet Bayur, Türk İnkilap Tarihi (1914-1918) Genel Savaşı), 3/4, (Ankara: TTK, 1991) 679-680; Renouvin, Birinci Dünya Savaşı ve Türkiye(1914-1918), 681-686.

64 Sofya Sefaretinden Hariciye Nezaretine 11 Ağustos 1918 tarihli şifrenin sureti, BOA, HR.ŞFR (04) 287/79, lef.1-2. 
Diğer taraftan Safa Bey, delillendiremese de Malinof Hükümetinin tek başına barış yolunu takip etmesini, Bulgaristan siyasetinde değişiklikler yaşanmasını ihtimal dış1 görmemiştir ${ }^{65}$. Nitekim Osmanlı makamları farklı kaynaklardan Bulgarların Amerika ve İngiltere ile tek başına barış görüşmeleri yaptığına dair bilgiler gelmekteydi. Osmanlı Devleti'nin Bern Sefirliğine göre, Bulgaristan'ın Bern maslahatgüzarı Amerika’nın Bern sefareti vasıtasıyla İtilaf Devletlerine "sulh-i münferid” teklifinde bulunmuştu. Ancak Osmanlı Sefaret yetkilileri, bu bilgiyi Bulgar maslahatgüzara teyit ettirememişti.

Osmanlı Devleti'nin Bern sefirliğine göre Bulgarlarla İtilaf Devletleri arasında barış görüşmelerine dair görüşmeler ilk değildi. 1918 Temmuz'unda İngiliz yetkililer ve İngiltere Avam Kamarası üyesi olan biri, Bulgarlarla temas kurmuşlardı. Avam Kamarası üyesi bu şahıs, Bulgaristan ile İtilaf Devletleri arasında barış imzalanması adına Makedonya cephesinde propaganda yapmak için görevlendirilmişti. Bu görev çerçevesinde Bulgaristan'da barış taraftarı olan devlet adamlarıyla irtibat kuracaktı. Aynı zamanda Cenevre'de bazı İngiliz yetkililer, Bulgarlarla "sulh münferid" hususunda gizli görüşmeler yapmaktaydılar ${ }^{66}$.

Osmanlı Devleti, Bulgarların Amerika Birleşik Devletleri ve İsviçre'de İngilizlerle yaptıkları bu barış görüşmelerine dair bilgiler üzerine, Ağustos 1918'de müttefikleri nezdinde harekete geçecektir. 20 Ağustos 1918'de Bulgarların barış görüşmeleri yaptığına dair İstanbul'daki Alman sefir ve Avusturya maslahatgüzarı özel olarak bilgilendirilmiştir. $\mathrm{Bu}$ girişimler için gerekli önemlerin alınması istenmiştir. Hatta Alman sefirine Bulgarların girişimlerine "tavassut" eden şahısların isimleri verilmiştir ${ }^{67}$.

\section{Sonuç}

Osmanlı Devleti I. Dünya Savaşı'nda İttifak Devletleri yanında yer almak zorunda kalmıştı. Bu savaş esnasında mücadele için gereksinim duyduğu askeri ve iktisadi her türlü desteği, müttefiklerinden sorunsuz olarak temin etmesi gerekiyordu. Bu destek için birçok yol kullanılabilirdi. Ancak maliyeti az, güvenli ve kesintisiz bir şekilde istediği desteği alabileceği en iyi ve kolay yol Bulgaristan toprakları idi. Özellikle Eylül 1914'ten itibaren Boğazları kapatması ve Rusların Karadeniz limanlardaki baskın ve ablukaları, Osmanlı Devleti'nin dış dünya ile iletişimini büyük oranda kesintiye uğramıştı. Bu yüzden Bulgaristan'ı desteği Osmanlılar için kaçınılmaz idi. Zira Bulgaristan'ın İttifak Bloku saflarında savaşa katılması Alman ve Avusturya-Macaristan devletleriyle kesintisiz toprak irtibatının sürdürebilmesi anlamına gelmekteydi.

Ancak Bulgaristan'da İttifak Bloku'na yakın bir kral ve başbakan bulunmasına rağmen savaşa hangi safta girilmesi hususunda bir beklenti vardı. Beklentinin bir nedeni savaşan taraflar arasında üstünlüğün hangisinde olduğunu görmek, diğeri ise harbe katılmaları

65 Sofya Sefaretinden Hariciye Nezaretine 11 Ağustos 1918 tarihli şifrenin sureti, BOA, HR.ŞFR (04) 287/79, lef.1-2.

66 Bern Sefaretinden Hariciye Nezaretine 27 Eylül 1918 tarihli telgraf, BOA, HR. SYS. 2327/7, lef.17.

67 Bulgaristan'ın sulh faaliyeti ve tutumu hakkında 20 Ağustos 1918 tarihli tutulan müsvedde, BOA, HR. SYS. 29807/90, lef 1-2. 
halinde Makedonya ve Dobruca'daki emellerini garanti altına almak yatıyordu. Bu yüzden Bulgaristan'ın resmen ve İttifak Bloku'nda savaşa dâhil olması I. Dünya Savaşı'nın başlangıcından yaklaşık 14 ay sonra gerçekleşebilmiştir. Bulgaristan'ın İttifak Devletleri safında yer almasında Bulgar Kralı ve başbakanının siyasi eğilimlerinden daha fazla, Çanakkale Cephesinde İtilaf Ordularının mağlubiyeti, Balkanlarda kendi lehine sınır düzenleme vaatleri ve bu sayede Osmanlı Devleti'nden elde ettiği toprak kazanımları, bir başka ifade ile tavizler belirleyici olmuştur.

Bulgaristan'ın savaşa girmesi ile birlikte Osmanlı Devleti, savaşı sağlıklı bir şekilde sürdürebilmesi için önemli bir kazanım elde etmişti. Bu gelişmeden sonra Osmanlı Devleti için Bulgaristan, kaybedilmemesi gereken konuma sahip bir müttefik devlet haline gelmiştir. Osmanlı makamları Bulgaristan ile ilişkilerini sağlıklı ve dengeli bir şekilde sürdürme çabası içinde olmuştur. Nitekim bu müttefiklik sürecinin başında Osmanlı Devleti, Türk ve Müslüman ahalinin vatandaşlık, askerlik ve yer yer kötü muameleye maruz kalma benzeri hususları sadece Bulgar makamları nezdindeki girişimlerle sonlandırmaya çalışmıştır.

Ancak İttifak Bloğunun önemli kazanımlar elde ettiği 1918 yılının ilk 5 ayı içinde imzalanan Brest-Litovsk ve Bükreş Antlaşmaları, Osmanlı-Bulgar ilişkilerinde önemli yaralar açmıştır. Hâlbuki her iki antlaşma da İttifak Bloku'nun başarılarının birer nişanesi idi. Brest-Litovsk Antlaşması çerçevesinde mağlup Rusya'nın donanmasının akıbeti, paylaşımı Karadeniz'e sahili olan Bulgaristan ve Osmanlı Devleti'ni çok yakından ilgilendirmekteydi. Zira Rus Donanmasındaki gemilerin hangi devlete terk edileceği tartışması, Karadeniz'de avantaj kazanma, söz sahibi olma hususunun önemli bir parçası idi. Her iki devlet ve basını kendi veçhelerinden haklılıklarını ortaya koyma ve avantajlı çıkma çabasındaydı.

Osmanlı Devleti ile Bulgaristan arasında sorunları derinleştiren ve müttefikler arasında çatışmaları artıran en önemli gelişme Bükreş Antlaşması olmuştur. İtilaf Devletleri safinda yer alan Romanya Devleti, Alman, Avusturya-Macaristan, Bulgaristan ve Osmanlı ordularının ortak harekâtı sonucunda mağlup edilmiş ve nihai barış antlaşması Bükreş’te imzalanmıştı. Bu antlaşma esnasında Kuzey Dobruca'nın geleceği dört İttifak Devletinin ortak yönetimine bırakılmıştı. Özellikle Osmanlı Ordusunun Romanya'nın mağlubiyetinde rol alması, Osmanlıların İttifak Bloku'nda söz sahibi olmasını, görüşme masasında sesini yüksek olarak çıkarmasını sağlamıştı. Bu noktada Osmanlı Devleti ve adeta onun sözcülüğünü yapan Osmanlı basını Kuzey Dobruca karşılığında 1915 Osmanlı-Bulgar sınır düzenlemesine dair antlaşmayı gündeme taşımışlardır. Osmanlı tarafı Osmanlı-Bulgar sınırında yeni düzenlemeler yapılmasını istemişler, hatta bazı Osmanlı basını Batı Trakya ve Doğu Rumeli coğrafyasına dair taleplerde bulunmuşlardı. Bulgaristan'daki bütün basın ise, Osmanlıların Kuzey Dobruca ve Osmanlı-Bulgar sınırıyla ilgili düzenlemelerine dair söylemlerine/yaklaşımlarına karşı tezler ileri sürmüşlerdir. Bu noktada İtilaf Devletleri basınının bu çatışmayı körüklediği görülmektedir.

İşte Osmanlılar ve Bulgarlar arasında bu sert tartışmaların ve fikir ayrılıklarının yaşandığı 
bir esnada, Demokrat Parti lideri A. Malinof'un başbakanlığa getirilmesi dikkatle izlenmesi gereken bir husustur. Her ne kadar Bulgaristan'da sıkışan siyasi sorunların çözümü için Demokrat Parti'nin iktidarının önünün açılması bir teamül ise de, başbakanlığa V. Radoslavof yerine Malinof'un getirilmesi, Osmanlı makamlarını endişelendirmiştir.

Kral Ferdinand dâhil, Bulgaristan'daki en yetkili kişiler ve basın tarafından bu endişeler izale edilmeye çalışılsa da, bütünüyle ortadan kaldırılamamıştı. Zira birçok husus Osmanlı makamlarının gözünden kaçmamaktaydı. Bu meyanda ilk olarak başbakanlığa Malinof gibi bir siyasi kimliğin getirilmesi önemli idi. Malinof, İttifak Bloğunda uzun bir süredir yer alarak çeşitli ilişkiler kuran ve Kuzey Dobruca-Meriç sınırı tartışmalarında masada kalan Radoslavof yerine başbakanlığa getirilmişti. Osmanlı makamları ve basını bilmekteydi ki Malinof'un siyasi geçmişinde Bulgaristan’ın Osmanlı Devleti’nden bağımsızlaşması gibi Osmanlılar aleyhinde birçok vaka yaşanmıştı. En önemlisi Malinof, I. Dünya Savaşı öncesi ve esnasında farklı tonlarda olsa da, İtilaf yanlısı olduğunu göstermişti. Kuzey DobrucaMeriç sınırı meselesinde Bulgar, uluslararası basın ve Türk makamlarına verdiği beyanlarda tavizsiz bir tavır takınmış, adeta yok saymıştı.

Bu meyanda Bulgaristan'ın İttifak Bloğundan ayrı olarak sulh-i münferid yapacağına dair söylentilerin Malinof'un iktidara gelmesiyle birlikte keskin bir şekilde ortaya çıkması üzerinde durulmalıdır. Bu noktada Bulgaristan'ın İtilaf Devletleriyle barış yapma düşüncesi, hatta Malinof'un iktidara gelişi, İttifak Bloğu sayesinde I. Dünya Savaşı'nda elde etmiş olduğu mevcut toprak kazanımlarını koruma çabası olarak değerlendirilebilir. Nitekim Wilson Prensiplerinin ilan edildiği bir dönemde Bulgarlar işgal ettikleri topraklarda kendi 1rkdaşlarının çoğunlukta bulunduğunu iddia etmekteydiler. Diğer taraftan Malinof'un Kuzey Dobruca hususundaki tavizsiz söylemi, İttifak Bloğunda bir parçalanma istemeyecek Alman ve Avusturya-Macaristan devletlerini etkilemek olarak da değerlendirilebilir. Nitekim Alman makamları Osmanlı Devleti ile Bulgaristan arasında yaşanan tartışmalarda, her iki ülkeye de eşit mesafede olduklarını ilan etmek zorunda kalmışlardı. Hâlbuki Bükreş Antlaşması sürecinde Almanya, Osmanlı tezlerini destekleme yönünde adımlar atmıştı.

Bütün bu gelişmeler ve değerlendirmeler 1şı̆̆ında 8 Ağustos 1918'de batı cephesinde İtilaf Ordusu karşısında Almanların mağlup olarak manen çökmesinden önceki bir tarihte, Bulgaristan'da A. Malinof'un başbakanlığa getirilmesi ve ardından yaşanan süreç/olaylar, İttifak Bloku için erken bir dönemde sağlıklı sonuçlar ortaya çıkarmadığını göstermektedir. 1918'de her iki bloğun siyasi çevrelerinde ve kamuoylarında savaşı sürdürmede zorluk, isteksizlik ve barış arzusu bulunmasına rağmen Bulgaristan Başbakanı Malinof'un müttefikleriyle kurduğu ilişkiler, kendi döneminde Bulgar ordusunun kaçmasıyla birlikte Makedonya cephesinin çökmesi ve ardından Selanik Mütarekesinin imzalanması, Osmanlılar, dolayısıyla İttifak Bloğunun I. Dünya Savaşı'ndaki mağlubiyetinin bir parçası olmuştur. Bunun önemli nedenlerinden biri Malinof'un iktidara geldiğinden itibaren uyguladığı politikaların bir yandan Osmanlı-Bulgar ilişkilerini diğer taraftan İttifak Bloku içinde kurulan statükoyu bozmasıdır. 


\title{
Kaynaklar
}

\section{Arşivler}

\section{Başkanlık Osmanlı Arşivi ${ }^{68}$}

Bab-ı Ali Evrak Odası

Dahiliye Nezareti İdare-i Umumiye Ek Belgeleri

Hariciye Nezareti Idare

Hariciye Nezareti Siyasi (HR. SYS.)

Hariciye Nezareti Şifre Kalemi

Hariciye Nezareti Tercüme Odasl

Irade Hariciye Nezareti I.HR

Sadaret Eyalet-i Mümtaze Bulgaristan Evrakı

\author{
Gazeteler $^{69}$ \\ Ati \\ Ikdam \\ Sabah \\ Tanin, \\ Tasvir-i Efkâr \\ Vakit \\ Zaman
}

\section{Kitap ve Tezler}

Alkaç, Ömer. Türk Basınında Mondros Mütarekesi Öncesi Barış Beklentisi, Yüksek Lisans Tezi, Erciyes Ü., 2015.

Bayur, Yusuf Hikmet. Türk Inkılâp Tarihi (1914-1918) Genel Savaşı), 3/4. Ankara: TTK, 1991.

Bıyıklığlu, Tevfik, Trakya'da Milli Mücadele I, Ankara, 1987.

Birinci Dünya Harbi, Avrupa Cepheleri (Makedonya Cephesi), 7/3, Ankara: Genelkurmay Harp Tarihi Yayınları, 1996.

Crampton, R.J. Bulgaristan Tarihi. Hazırlayan Nuray Ekici. İstanbul: Jeopolitika Yay., 2007.

Okyar, Fethi. Üç Devirde Bir Adam. Hazırlayan Cemal Kutay. İstanbul: Tercüman Yayınları, 1980.

Özbek, Zeynep. 1918 Yılı Türk Basınında Bulgaristan'ın Savaş Politikasıyla İlgili Değerlendirmeler, Yüksek Lisans Tezi, Erciyes Üniversitesi, 2014.

Renouvin, Pierre. 1. Dünya Savaşı ve Türkiye (1914-1918). İstanbul: Örgün Yay., 2004.

Tarihte Türk-Bulgar İlişkileri. Ankara: Genelkurmay Askeri ve Stratejik Etüt Dire Başkanlığı Yay., 2004.

Türkgeldi, Âli. Moudros ve Mudanya Mütarekelerinin Tarihi. Ankara: Türk Devrim Tarihi Enstitüsü Yay., 1948.

68 Arşiv belgelerinin numaraları metin içinde gösterilmiştir

69 Gazetelerin tarihleri metin içinde gösterilmiştir. 


\section{Makaleler}

Başkaya, Muzaffer. “İngiliz Basınına Göre Bulgaristan’ın Birinci Dünya Savaşı’ndan Çekilişi ve Selanik Antlaşması", Akademik Incelemeler Dergisi, 10/1 (2015): 51-74.

Dabrov, Angel. “1915 Yılında Bulgar-Türk Sınırının Düzeltilmesi”, XX. Yüzyılın İlk Yarısında Türk-Bulgar Askeri-Siyasi İlişkileri, Ankara, (2005): 1-7.

Sancaktar, Fatih M. “Ali Fethi (Okyar) Bey’in Bulgaristan Sefirliği Dönemindeki Faaliyetleri (Ekim 1013-Aralık 1917)”, Atatürk Araştırma Merkezi Dergisi, 27/81 (2011): 577-602.

Yiğit, Ali Ata. "Çanakkale Savaşlarının Ortaya Çıkardığı Stratejik Bir Zorunluluk: Osmanl1-Bulgar Hudud Tashihi Antlaşması”, Bilig, 63 (2012): 273-277. 